\title{
Clay mineral formation in Permian rocks of a geothermal borehole at Northern Upper Rhine Graben, Germany
}

\author{
Lan Nguyen-Thanh ${ }^{1}$ (D) Rafael Ferreiro Mählmann ${ }^{1} \cdot$ Thao Hoang-Minh $^{2} \cdot$ Rainer Petschick $^{3} \cdot$ Thomas Reischmann $^{4}$. \\ Heinz-Dieter Nesbor ${ }^{4}$ Myriam Ruttmann ${ }^{4} \cdot$ Johann-Gerhard Fritsche ${ }^{4}$
}

Received: 29 June 2020 / Accepted: 28 February 2021 / Published online: 27 March 2021

(c) The Author(s) 2021

\begin{abstract}
Hydrothermally altered rhyolite rocks in the Permian Donnersberg Formation of a geothermal borehole in the Northern Upper Rhine Graben (Germany) were investigated to find out answers for the low hydraulic conductivity of the rocks. The composition of clay minerals and the temperature of smectite-illite transformation were carried out using X-ray diffraction, X-ray fluorescence, transmission electron microscopy, Fourier transform infrared spectroscopy, and polarized-light microscopy analyses. Clay mineral (CM) composition includes illite/muscovite ( $1 M$ and $2 M_{1}$ polytypes), illite-smectite interstratifications (IS-ml), smectite, and chlorite; and non-clay minerals such as quartz, feldspars, epidote, calcite, dolomite, and hematite were detected. The $2 M_{1}$-polytype mica might be the only primary sheet silicates from the parent rocks, while the others occur as authigenic neo-formed CMs under heat flow and geothermal gradient. The development of CMs indicates different mechanisms of illitization and smectitization. Based on the texture, morphology, structure/polytype, and chemistry of rocks and minerals, in particular $\mathrm{CMs}$, the study grouped the $\mathrm{CM}$ formation into three transformation processes: smectitization during magma cooling and possible contact metamorphisms with decreasing and low temperature, smectite illitization controlled by burial diagenesis and hydrothermal alteration, and illite smectitization followed exhumation and Cenozoic subsidence with decreasing temperature. The rhyolites were altered to all of the orders IS-R0, IS-R1, and IS-R3 by the dissolution-precipitation and layer-to-layer mechanisms. The first one supported small xenomorphic plates and flakes of $1 M_{d}$, elongated particles of $1 M$, and pseudo-hexagonal forms of $2 M_{1}$. The second one could lead to the platy particles of $1 M_{d}$ and $2 M_{1}$ polytypes. The dominant temperature range for the transformation in the area has been $140-170{ }^{\circ} \mathrm{C}-\sim 230^{\circ} \mathrm{C}$.
\end{abstract}

Keywords Geothermal borehole · Clay mineral · Smectite illitization · Thermal gradient · Upper Rhine Graben · Donnersberg Formation

Lan Nguyen-Thanh

nguyen@geo.tu-darmstadt.de

1 Technische Universität Darmstadt, 64287 Darmstadt, Germany

2 University of Science, Vietnam National University, Hanoi, Hanoi 10000, Vietnam

3 Goethe University Frankfurt, 60438 Frankfurt am Main, Germany

4 Hessian Agency for Nature Conservation, Environment and Geology, 65203 Wiesbaden, Germany

\section{Introduction}

\section{Structure of IS-ml and transformation between smectite and illite}

The orders of IS-ml particles were determined by the Reichweite parameter (Jagodzinski 1949) with the increasing of the illitic layer from randomly ordered (IS-R0), to shortrange ordered (IS-R1), and to long-range ordered (IS-R3) (Reynolds and Hower 1970; Pytte and Reynolds 1989). Correspondingly, the polytypes are $1 M_{d}$ (turbostratic orientation), $1 M$ (block-wise orientation), and $2 M_{1}$ (unique orientation). Besides, illite aggradation zones (low-grade diagenetic zone, high-grade diagenetic zone, anchizone, and epizone) were determined using the Kübler Index (KI) (Kübler 1967; reviewed by Ferreiro Mählmann et al. 2012). 
"Smectite illitization", or smectite-to-illite transformation, is termed for the conversion of smectite into illite via a series of interstratifications. This process normally was accompanied with burial diagenesis of argillaceous sediment, very low-grade metamorphism, or contact metamorphism (Hower et al. 1976; Hoffmann and Hower 1979; Hower 1981; Inoue et al. 2004). Starting from the solid-state transformation concept of Reynolds and Hower (1970) (verified later by Elliot and Matisoff 1996), several authors used this transformation process to reconstruct the thermal and tectonic history of sedimentary basins (Weaver 1960; Hoffmann and Hower 1979; Schoonmaker et al. 1986), to understand active hydrothermal systems (Jennings and Thompson 1986), or to estimate thermal maturity in petroleum geology (Weaver 1960; Teichmüller et al. 1983). Besides, the smectite illitization was also significant to explain the hydrothermal alteration or geothermal history (Horton 1985; Jennings and Thompson 1986; Bauluz et al. 2002).

The prograde smectite-to-illite and retrograde illite-tosmectite transformations with the related data (e.g., illite polytype, mineral index, facies, organic matter index, and fluid chemistry) were used as indicators for diagenetic grade, temperature, and mechanism (Ferreiro Mählmann 2001; Środoń et al. 2002; Clauer 2006; Árkai et al. 2012; Bozkaya et al. 2016). Whitney (1990) stated that the smectite illitization rate decreases with increasing of the water activity, but Mullis et al. (2002) also mentioned that the smectite stability limit depends strongly on the fluid chemistry, which inludes $\mathrm{K}^{+}$content. The dissolution of $\mathrm{K}$-feldspars also releases $\mathrm{K}^{+}$ and $\mathrm{Al}^{3+}$, which are needed for illitization. The greater the availalbility of $\mathrm{K}^{+}$and $\mathrm{Al}^{3+}$, the higher the rate of smectite illitization. However, several factors, such as geologic time, water/rock ratio, permeability, grain size, pressure, and chemistry of rock, will contribute and engage in the smectite illitization (Pytte and Reynolds 1989; Huang et al. 1993; Merriman and Peacor 1999).

\section{Factors affecting IS-mI struture}

The structural orders and polytypes of IS-ml depended strongly on temperature and depth (Hower et al. 1976; Velde 1985; Pollastro 1993). The temperature determination through the transformation between smectite and illite was questioned (Jiang et al. 1990), but this process could provide the approximate maximum temperature reached the equilibrated condition (Pollastro 1993; Essene and Peacor 1995; Merriman and Peacor 1999).

Heat flow is another temperature factor affecting metastable the formation of IS-ml. Discrete smectite could be changed to IS-ml at a minimum temperature of $80{ }^{\circ} \mathrm{C}$ as shown by Huang et al. (1993) or Hillier (1995). The early numerical models even pointed out that the same step of the illitization could happen at lower temperatures (Hoffmann and Hower 1979; Jennings and Thompson 1986), but different higher temperatures were frequently found (Steiner 1968; Weaver and Beck 1971; McDowell and Elders 1980).

The relationship between the IS-ml structure and burial temperatures has been attracted attention from many researchers. Velde (1965) and Frey (1987) suggested that $\mathrm{CM}$ and their structural changes provide useful information about the geodynamic setting in the very-low-temperature range $\left(<300^{\circ} \mathrm{C}\right)$ of crustal rocks. Weaver (1953) also concluded that during the burial diagenesis and epithermal process, discrete smectite transformed to IS-ml, and then to illite. Hower et al. (1976) and Velde and Nicot (1986) reported increasing trends of depth and illitic layer in IS-ml toward IS-R3 in quaternary and tertiary sediments. In the young sedimentary basins, IS-R0 was transformed to IS-R1 at about $80{ }^{\circ} \mathrm{C}$, which helped to find out the hydrothermal gradient of $35^{\circ} \mathrm{C} / \mathrm{km}$ (Hower et al. 1976).

Diagenetic zone as the combination of temperature and depth leaves a mark on the IS-ml structure. The transformation from mudstones to shale, and from the boundary of the low-grade zone to the high-grade diagenetic zone and anchizone leads the evolution from IS-R0 to IS-R1 and IS-R3 paralleling the polytype change from illite $1 M_{d}$ to $1 M$ and $2 M_{1}$ (Merriman and Peacor 1999; Ferreiro Mählmann 2001; Bailey 1988; Dalla Torre and Frey 1997). At the diagenetic zone, the $17 \AA$ discrete smectite disappeared and a mean temperature around $100{ }^{\circ} \mathrm{C}$ was postulated by Merriman and Peacor (1999). According to Eslinger and Savin (1973), smectite and IS-ml will be replaced completely by illite at the temperature between 200 and $230{ }^{\circ} \mathrm{C}$. Based on KI investigation, discrete smectite also disappeared in all other sedimentary rocks of the diagenetic zone with the upper limit of $230{ }^{\circ} \mathrm{C}$ (Ferreiro Mählmann et al. 2012) or showed its stability limit at $200{ }^{\circ} \mathrm{C}$ (Velde 1977; Brauckmann 1983; Kisch 1987), but still occurred in carbonate rocks of the anchizone grade (Frey 1970; Ferreiro Mählmann 1994).

When moving from low-grade diagenetic zone to highgrade diagenetic zone, smectitic layers can be reduced very fast from 100 to 50\% (Środoń and Eberl 1984); otherwise, IS-ml with the smectitic/illic layer ratio of 1:1 are stable in a wide temperature range (Frey 1987; Horsfield and Rullkötter 1994; Merriman and Kemp 1996; Merriman and Frey 1999). Moreover, the ordered IS-ml particles were found in $<15 \%$ smectite-bearing clay fraction taken from the diagenesis/ anchizone boundary at $230{ }^{\circ} \mathrm{C}$ (Ferreiro Mählmann 2001), but contrary to at temperatures of $100-120{ }^{\circ} \mathrm{C}$ (Dunoyer de Segonzac 1970; Velde 1977), and one reason is the geologic time.

Hillier et al. (1995) used smectite kinetic models with the diagenetic evolution between 5 and $300 \mathrm{Ma}$ and concluded that IS-R 1 appeared at $100-110^{\circ} \mathrm{C}$, but with a shorter burial time, the corresponding temperature was $120-140{ }^{\circ} \mathrm{C}$. The illitization to IS-R 3 could be happened at about $180^{\circ} \mathrm{C}$ 
(Steiner 1968; Weaver and Beck 1971; McDowell and Elders 1980). Otherwise, transformation from IS-R1 to IS-R3 was also time-dependent at about $170-180{ }^{\circ} \mathrm{C}$ (Hoffmann and Hower 1979; Jennings and Thompson 1986).

Illite was dominant in the anchizone, but, in the same zone, the total smectitic layer in IS-ml could cover the full range of 0-100\% (Ferreiro Mählmann 1994, 2001). The $1 M$ polytype might be formed hydrothermally earlier than burial anchizonal conditions and disordered structures are absent from anchizone, but during transformation, a mixture of $1 M$ and $2 M_{1}$ polytypes could occur (Dalla Torre and Frey 1997). Fully unexpandable illite could achieve at $>200{ }^{\circ} \mathrm{C}$ (Huang et al. 1993; Hillier et al. 1995). However, by recalibration the limit of the KI of diagenetic zone, Ferreiro Mählmann $(1994,2001)$ and Mullis et al. $(2002,2017)$ found smectite at $>230{ }^{\circ} \mathrm{C}$ of slight hyperthermal conditions, and consequently, the upper most temperature limit for stability of IS-ml lies at $300{ }^{\circ} \mathrm{C}$. The long-range ordered illite $2 M_{1}$ polytype appeared in epithermal conditions at $125-350{ }^{\circ} \mathrm{C}$ (Velde 1965); and made up 90\% of IS-ml in the anchizone samples with the smectitic layer range of 70-90\% (Dalla Torre and Frey 1997), as well as evolved to $100 \%$ in the lower boundary of epizone (Ferreiro Mählmann 2001). It is evident that at hydrothermal conditions, an earlier longrange ordered structure could be crystallized. Therefore, the successful models could not be universally applied in different basins with different thermal subsidence histories (Elliot and Matisoff 1996).

In conclusion, the transformation from IS-R0 into IS-R1 in the hydrothermal system happed at temperatures, minimum at $80^{\circ} \mathrm{C}$ and maximum at $140{ }^{\circ} \mathrm{C}$. The temperature to form the IS-R3 is at least $170{ }^{\circ} \mathrm{C}$, and the discrete smectite will transform completely to IS-R3 at higher than $230^{\circ} \mathrm{C}$.

\section{Clay mineral studies for geothermal energy exploration in the Upper Rhine Graben}

The Upper Rhine Graben (URG) had favorable conditions for energy exploration due to the highest geothermal gradient (more than $7.7^{\circ} \mathrm{C} / 100 \mathrm{~m}$ ) in Germany (Illies and Fuchs 1974). Therefore, Germany and France implemented several geothermal projects in the main Triassic geothermal reservoirs of the graben. However, Northern URG was not considered as a geothermal resource because of lacking Mesozoic deposits due to an unconformity of Tertiary rocks. Later, in 2016, one borehole of nearly $3700 \mathrm{~m}$ vertical depth was drilled in a field near Groß-Gerau (Northern URG) (Fig. 1) by a local energy supplier for hydrothermal exploration (Kreuter 2016). According to Hessian Agency for Nature Conservation, Environment and Geology (HLUNG 2010) and Wenke et al. (2010), the high geothermal gradient (up to $5.6{ }^{\circ} \mathrm{C} / 100 \mathrm{~m}$ ) in the vicinity was well known from hydrocarbon boreholes targeting at reservoirs in the tertiary sediments in the depth of less than $2000 \mathrm{~m}$. The much deeper Permian Donnersberg Formation was the geothermal exploration target due to the expected high hydraulic conductivity and the high temperature. Sediments and volcanic rocks in this formation were partly-to-completely altered to form a high amount of CMs, especially micaceous minerals (illite), which dramatically influenced the host rocks and the available heat flow conditions (e.g., permeability and heat conductivity) (Charléty et al. 2007; Bartier et al. 2008).

Diagenetic transformation of smectite to illite in Cenozoic sediments, especially tertiary sediments, in Northern URG was the research objective of many scientists a long time ago (Heling 1974, 1978; Heling and Teichmüller 1974; Doebl et al. 1974). They found that the smectite phases were formed at temperatures between 70 and $80^{\circ} \mathrm{C}$, and the transformation rate was controlled by time-dependent induced heat. From the recent geothermal exploration projects with deep boreholes at Soultz-sous-Forêts and Rittershoffen (France, Central URG), several publications have stated on the hydrothermal alteration to CMs including illite of the granite and Permo-Carboniferous argillic rocks (Schleicher et al. 2006; Vidal et al. 2018).

Up to now, no attention paid to the diagenetic formation of micaceous minerals or the other CMs (e.g., chlorite), as well as on the relationship between clay mineralogy and thermal maturity of reservoir rocks in Northern URG. In particular, the order, structure, and composition of CMs have not been identified. Therefore, this study characterized in detail the mineralogical composition and the formation of CMs during hydrothermal alteration and burial diagenesis, then discussing the thermal evolution of the volcanic rocks at the depth of nearly $3700 \mathrm{~m}$ and their effects on properties of reservoir rocks. Moreover, observation from other minerals, e.g., alteration of feldspar, transformation from biotite to chlorite, and growing of epidote on plagioclase, was also taken into account to estimate the thermal grade of the rocks, because the chemical consequence of these processes could affect the migration of hydrothermal fluids. The formation of cementing minerals can directly influence the geothermal flow rate by reducing the rock porosity and thus the permeability. Finally, understanding the mineralogical crystallization will lead to a better understanding of the thermal and geochemical history of the rocks. The results also may support the geothermal exploration in Permo-Carboniferous Rotliegend rocks, Northern URG.

\section{Geological setting and hydrothermal system}

\section{Geological setting}

URG belongs to the European Cenozoic rift system, which extends from Western Mediterranean to North Sea. The 


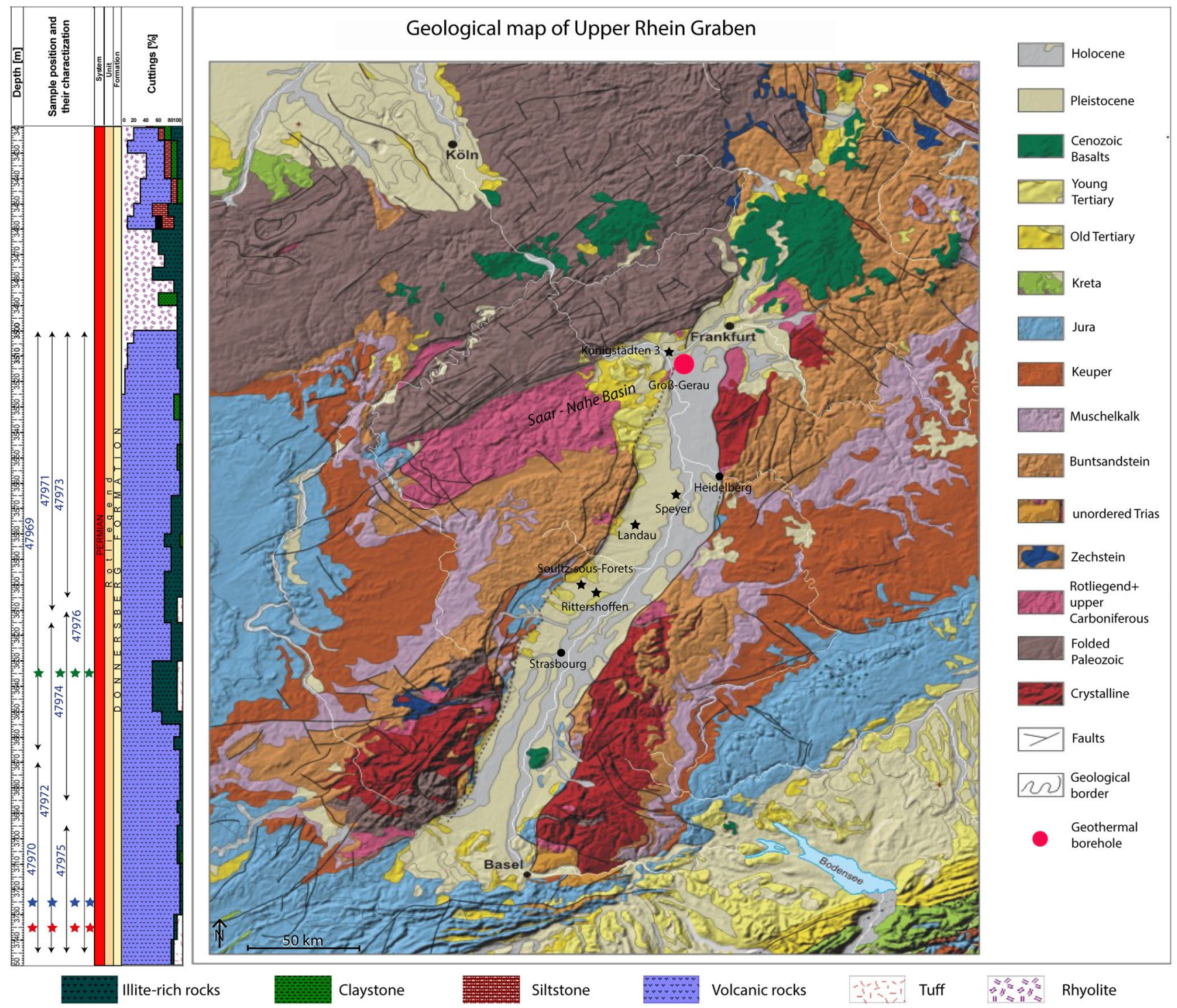

Fig. 1 Geological map of Upper Rhine Graben [adapted from Röhr 2006 basing on geological data of Lahner and Toloczykl 2004 and morphological data of GTOPO30 (left)] with sampling location and description of picked materials in geothermal borehole (right)

geothermal site near Groß-Gerau (Germany) is situated in Northern URG, where a recent thermal gradient was estimated up to $5.6{ }^{\circ} \mathrm{C} / 100 \mathrm{~m}$ (HLNUG 2010; Wenke et al. 2010) (Fig. 1 left). The Cenozoic structural evolution and the fault block geometry have been published widely (Rothe and Sauer 1967; Illies and Fuchs 1974; Prodehl et al. 1995; Schumacher 2002; Dezes et al. 2004). The tectonic activities related to the rift formation were characterized by two phases: (1) the rift was extensionally opened, induced by the collision events due to movement of the Alpine deformational front on the European plate from Eocene (since $45 \mathrm{Ma}$ ) to Early Neogene, and (2) the strike-slip regime followed from Early Neogene (Illies 1975; Schwarz 2005).

The URG basin extends from Basel (Switzerland) NNE-trending to the south of Frankfurt (Germany) along a distance of $330 \mathrm{~km}$. Since the Variscan orogenesis, forming the basement rocks, the area subsequently underwent late-orogenic extension $(\approx 300 \mathrm{Ma})$. From the Permian $(\approx 270 \mathrm{Ma})$ to the end of the Jurassic period $(\approx 145 \mathrm{Ma})$, sediment deposition in a thermo-tectonic subsidence setting was characterized by the up to $2 \mathrm{~km}$-thick succession of sedimentary rocks of the Franconian platform (Ziegler and Dezes 2005). The depocentre was part of the SSW-oriented embayment of the German basin and the Burgundian gateway (Ziegler and Dezes 2005), an extensional precursor of URG controlled by a pre-graben lithospheric shear zone (Grimmer et al. 2017). The graben formation was a reactivation of inherited Variscan structures (Illies 1962; Eisbacher et al. 1989; Grimmer et al. 2017). During Cretaceous and Paleocene (70-40 Ma) regional uplift centered in Northern 
URG and was therefore induced by mantle plume rise and magmatism with a low percentage of partial mantle melts (Wimmenauer 1970; Wedepohl and Baumann 1999; Keller 2003).

In Northern URG, extension in the tertiary was characterized by normal faulting and strike-slip faulting of syn-sedimentary origin (Stollhofen 1998) with a total crustal extension of 6 to $>8 \mathrm{~km}$ (Meier and Eisbacher 1991; Schwarz and Henk 2005). They were controlled by the master fault system in the west and the graben fault system in the east. In the Late Cretaceous to Palaeocene volcanism and early extension overlap with the alkaline intraplate magmatism of the Central European Cenozoic volcanism changing the stress field in the URG area (Horn et al. 1972; Wimmenauer 1972, 1985; Keller 2003; Schmitt et al. 2007). During this phase, approximately $1.5 \mathrm{~km}$ of cover rocks was eroded causing an increasing gap at the Mesozoic/Tertiary hiatus from south to north in URG. The main syn-rift volcanic activities occurred in the Tertiary phases, which were accompanied by typical alkaline magmas of a rift valley (Keller et al. 1990; Reischmann 2011). The magmatic rocks are cropping out in form of dikes, plugs, necks, and diatreme pipes (Wimmenauer 1952; Keller et al. 1990). Otherwise, products of Permian, late Cretaceous-to-Paleogene, and Miocene volcanism were widely found in the area (Lorenz and Nicholls 1976).

Northern URG is made up of Palaeozoic basement rocks, Permian volcanic-sedimentary rocks, Cenozoic sedimentary rocks, and Quaternary sediments. In contrast to Southern and Central URG, Mesozoic strata were not preserved in this area (Plein 1992; Grimmer et al. 2017) with $2500 \mathrm{~m}$ of eroded overburden (Henk 1992, 1993; Müller 1996; Stollhofen 1998; Aretz et al. 2015). Tertiary sediments of Northern URG are overlaying directly on the Permo-Carboniferous Saar-Nahe Basin, which is composed mainly of clastic continental sediments (Korsch and Schaefer 1991) and magmatic rocks of sub-alkaline-calc-alkaline basalt, andesite, dacite, and rhyolite composition (von Seckendorf et al. 2004). The geothermal well near Groß-Gerau encountered different kinds of volcanic rocks as rhyolite, rhyodacite, andesite, and basalt. In the Tertiary sediments, a fracture zone was observed in the Miocene of Wiesbaden Formation (Hydrobien-Layer) with a high amount of CMs. An NE-SWstriking antithetic fault, dipping to NW, was reached at the depth of ca. $3500 \mathrm{~m}$ in the Standenbühl Formation. A fault zone was found at the depth of ca. $3770 \mathrm{~m}$ in the Donnersberg Formation. Finally, another fault zone farther to the east was plugged largely by calcite, gypsum, and secondary quartz.

In summary, URG is characterized by variable subsidences rates, Mesozoic tilting and exhumation, as well as the final Ceinozoic subsidence and burial. The geodynamic regime plays a role in the thermal evolution of the area, and thus impacts the temperature and composition of the rocks.

\section{Hydrothermal system}

URG was considered as an active geothermal system with a mean geothermal gradient of $30^{\circ} \mathrm{C} / \mathrm{km}$ to the depth of $6 \mathrm{~km}$ (Dornstadter et al. 1999). Several geothermal projects took advantage of the hot fluids in the Permo-Carboniferous parts of the basin for electricity, heating, and cogenerated energy (Sanjuan et al. 2016). By successive drilling exploration, this layer was reported with hyperthermal gradient values ranging from 40 to $60{ }^{\circ} \mathrm{C} / \mathrm{km}$ with fluids present in deep drills into the granite basement approaching the temperature of $225 \pm 25^{\circ} \mathrm{C}$ (Sanjuan et al. 2010, 2014). The near GroßGerau geothermal borehole and Königstädten 3 well (Fig. 1) situated in Northern URG yielded in situ temperature depth of $3400 \mathrm{~m}\left(140{ }^{\circ} \mathrm{C}\right)$ and $2500 \mathrm{~m}\left(152{ }^{\circ} \mathrm{C}\right)$ (Kreuter 2016). Thus, the fluids are expected to act as a heat source for the deep reservoir system in the studied area. Researches on the Soultz-sous-Forêts geothermal site, Dubois et al. (1996) and Smith et al. (1998) stated that the formation temperature of hydrothermal minerals with a broad salinity range during younger, post Oligocene up to the present-day fluid flow event is $130-160{ }^{\circ} \mathrm{C}$.

The chemical composition and temperature of the geothermal fluids are important factors controlling the dissolution-precipitation and alteration of rocks. Dezayes et al. (2015) collected and interpreted chemical data of geothermal fluids from 8 geothermal wells in Central and Northern URG and summarized that the fluids evolved into high brine $(\mathrm{NaCl}$ type) with $\mathrm{pH} 5-7$, enriched in $\mathrm{Ca}$ and $\mathrm{Li}$, and depleted in $\mathrm{Mg}$. The high salinity of fluids was developed by evaporation of meteoric water (Permian to Triassic period primary brine) together with halite-dissolution brine from evaporitic Triassic and Cenozoic formations as well as from high mineralized fluids residing in the crystalline basement (Stober and Bucher 2015; Regensburg et al. 2016) which derived from veins formed at 170-180 Ma from $\mathrm{Na}-\mathrm{Ca}-\mathrm{Cl}$ fluids (Burisch et al. 2017). The geothermometer of fluid solution calculated basing on the main cation, isotopic ${ }^{18} \mathrm{O}_{(\mathrm{H} 2 \mathrm{O})}{ }^{18} \mathrm{O}_{(\mathrm{SO} 4)}$, and $\mathrm{Li}$ isotopic signatures ranged from 200 to $240{ }^{\circ} \mathrm{C}$. Dezayes et al. (2015) also suggested that this temperature could be reached at Groß-Gerau, Riedstadt, Speyer, and Landau geothermal sites (Fig. 1). The origin was thought to be the results of the mixing of the primary marine brine (fossil pore water) and meteoric water. Sanjuan et al. $(2014,2016)$ found similar geochemical results of geothermal brines from the granitic basement in Soultz-sous-Forêts. Discrepancies in salinity, mass $\mathrm{Cl} / \mathrm{Br}$, total dissolved solids, and isotopic signature were detected differing from well to well. Brines from Rotliegend fluids are principal products of evaporation of sea water and later dissolution of evaporites in the Rotliegend formation were characterized by a high salinity with a $\mathrm{Na}$ and $\mathrm{Cl}$ dominance (Dezayes et al. 2015; Sanjuan et al. 2016). The origins of these fluids were suggested being strongly 
dependent on the meteoric water and marine water ratio. The higher the rate of dissolved evaporative halite, the greater $\mathrm{Cl} / \mathrm{Br}$ ratio is obtained; on the contrary, the lower the $\mathrm{Cl} / \mathrm{Br}$ ratio points to a contribution dominance of marine water.

\section{Samples and methods}

In this research, CMs in altered rhyolites and picked materials from the near Groß-Gerau geothermal borehole (Fig. 1, Table 1) have been investigated. Different established accurate methods recommended by Nieto and Do Campo (2020) were used to identify and characterize the mineralogical composition of the bulk rocks and the clay fractions $(<2.0 \mu \mathrm{m})$. X-ray diffraction (XRD) of randomly oriented powder specimens and Fourier transform infrared spectroscopy (FT-IR) techniques have been performed from whole rock fragments and picked materials. X-ray fluorescence (XRF) and polarized-light microscopy (PM) were used to characterize micro texture, mineralogical composition, and chemical composition of the bulk samples. XRD of oriented mounts (textured sedimented slides) was used parallel with transmission electron microscopy (TEM) to investigate the clay fraction $(<2.0 \mu \mathrm{m})$. In general, the combination of these methods allows to characterize the mineralogical composition of the bulk samples and the clay mineralogy of the clay fraction. Moreover, the combination allows to define the transformation process of CMs, to establish the relation between clay mineralogy and thermal grade of rocks.

Table 1 Description of investigated materials and methods applied

\begin{tabular}{|c|c|c|c|c|c|c|c|c|c|}
\hline \multirow[t]{2}{*}{ Sample } & \multirow[t]{2}{*}{ Depth (m) } & \multirow[t]{2}{*}{ Color } & \multirow[t]{2}{*}{ Phenocrysts } & \multirow[t]{2}{*}{ XRF } & \multirow[t]{2}{*}{ PM } & \multirow[t]{2}{*}{ FT-IR } & \multicolumn{2}{|l|}{ XRD } & \multirow[t]{2}{*}{ TEM } \\
\hline & & & & & & & Bulk samples & $\begin{array}{l}\text { Ori- } \\
\text { ented } \\
\text { mounts }\end{array}$ & \\
\hline $47969^{a}$ & $3500-3665$ & Green-grey & - & $\mathrm{x}$ & - & $\mathrm{x}$ & $\mathrm{x}$ & $\mathrm{x}$ & - \\
\hline $47970^{\mathrm{a}}$ & $3670-3745$ & - & - & $\mathrm{x}$ & - & $\mathrm{x}$ & $\mathrm{x}$ & $\mathrm{x}$ & $\mathrm{x}$ \\
\hline $47971^{\mathrm{a}}$ & $3500-3610$ & Dark green & - & $\mathrm{x}$ & - & $\mathrm{x}$ & $\mathrm{x}$ & $\mathrm{x}$ & $\mathrm{x}$ \\
\hline $47972^{\mathrm{a}}$ & $3615-3745$ & - & - & $\mathrm{x}$ & - & $\mathrm{x}$ & $\mathrm{x}$ & $\mathrm{x}$ & $\mathrm{x}$ \\
\hline $47973^{\mathrm{a}}$ & $3500-3605$ & Light green & - & $\mathrm{x}$ & - & $\mathrm{x}$ & $\mathrm{x}$ & $\mathrm{x}$ & - \\
\hline $47974^{\mathrm{a}}$ & $3610-3685$ & - & - & $\mathrm{x}$ & - & $\mathrm{x}$ & $\mathrm{x}$ & $\mathrm{x}$ & - \\
\hline $47975^{\mathrm{a}}$ & $3695-3745$ & - & - & $\mathrm{x}$ & - & $\mathrm{x}$ & $\mathrm{x}$ & $\mathrm{x}$ & - \\
\hline $47976^{\mathrm{a}}$ & $3500-3745$ & Pale green & - & $\mathrm{x}$ & - & $\mathrm{x}$ & $\mathrm{x}$ & $\mathrm{x}$ & - \\
\hline $72835^{\mathrm{b}}$ & 3635 & Pale green & Quartz, muscovite & - & $\mathrm{x}$ & & - & - & - \\
\hline $72836^{\mathrm{b}}$ & 3635 & Light green & $\begin{array}{l}\text { Quartz, sericitized feldspars, saussuritized plagio- } \\
\text { clase, muscovite, chlorite, epidote, Fe-oxides, } \\
\text { carbonate }\end{array}$ & & $\mathrm{x}$ & & - & - & - \\
\hline $72837^{\mathrm{b}}$ & 3635 & Dark green & Quartz, muscovite, hematite & & $\mathrm{x}$ & & - & - & - \\
\hline $72838^{\mathrm{b}}$ & 3635 & Green-grey & $\begin{array}{l}\text { Quartz, orthoclase, sericitized feldspars, saus- } \\
\text { suritized plagioclase, muscovite, tourmaline }\end{array}$ & & $\mathrm{x}$ & & - & - & - \\
\hline $72843^{c}$ & 3725 & Pale green & Fe-oxides & - & - & $\mathrm{x}$ & $\mathrm{x}$ & $\mathrm{x}$ & - \\
\hline $72844^{\mathrm{c}}$ & 3725 & Light green & - & - & - & $\mathrm{x}$ & $\mathrm{x}$ & $\mathrm{x}$ & $\mathrm{x}$ \\
\hline $72845^{\mathrm{c}}$ & 3725 & Dark green & Biotite & - & - & $\mathrm{x}$ & $\mathrm{x}$ & $\mathrm{x}$ & - \\
\hline $72846^{\mathrm{c}}$ & 3725 & Green-grey & - & - & - & $\mathrm{x}$ & $\mathrm{x}$ & $\mathrm{x}$ & - \\
\hline $72851^{\mathrm{d}}$ & 3735 & Pale green & $\begin{array}{l}\text { Quartz, orthoclase, sericitized feldspars, Fe-oxides, } \\
\text { garnet }\end{array}$ & - & $\mathrm{x}$ & $\mathrm{x}$ & $\mathrm{x}$ & $\mathrm{x}$ & - \\
\hline $72852^{\mathrm{d}}$ & 3735 & Light green & $\begin{array}{l}\text { Quartz, orthoclase, sericitized feldspars, Fe-oxides, } \\
\text { muscovite, chlorite-muscovite stacks, chlorite, } \\
\text { garnet }\end{array}$ & - & $\mathrm{x}$ & $\mathrm{x}$ & $\mathrm{x}$ & $\mathrm{x}$ & - \\
\hline $72853^{d}$ & 3735 & Dark green-red & $\begin{array}{l}\text { Quartz, orthoclase, sericitized feldspars, garnet, } \\
\text { tourmaline(?) }\end{array}$ & - & $\mathrm{x}$ & - & $\mathrm{x}$ & - & $\mathrm{x}$ \\
\hline $72854^{d}$ & 3735 & Green-grey & $\begin{array}{l}\text { Orthoclase, sericitized feldspars, saussuritized pla- } \\
\text { gioclase, biotite, muscovite, Fe-oxides (hematite), } \\
\text { carbonate }\end{array}$ & - & $\mathrm{x}$ & - & $\mathrm{x}$ & - & - \\
\hline
\end{tabular}

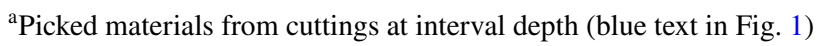

b,c,d Cuttings materials at 3635 m, 3725 m, and 3735 m (green, blue, and red stars, respectively in Fig. 1) 


\section{Samples}

Twenty samples of altered rhyolites from the deepest part (between 3500 and $3700 \mathrm{~m}$ ) of the near Groß-Gerau geothermal borehole in the Donnersberg Formation were described (Fig. 1, right). The age of the primary rock is likely of $296 \pm 2$ Ma (Lippolt et al. 1989). The rhyolite Donnersberg complex consists of 15 individual intrusive-extrusive bodies and the emplacement of this rhyolite accompanied by the eruption of ashes, ash flows, and tuffs Haneke (1987). They are composed mainly of silica-rich lava flows and inter-bedded phreatic-magmatic pyroclastic horizons, rhyodacites, and rhyolites, as well as acidic ash- and lapilli-tuffs (von Seckendorf et al. 2004). Quartz, K-feldspar, plagioclase (mostly albite), biotite, with accessories of zircon and apatite, as well as pyroxene and amphibole for some occurrences were identified for the rhyolite (Arikas 1986).

The samples were selected based on the diversity of petrography and phenocrysts of the rocks (Fig. 1 left, Table 1). A total of eight hand-picked materials (sample 47969-47976, Table 1) were collected with the depths given in interval due to the cutting type and unavailable precise location. Those materials changed from green grey to pale green and were notably altered. The cutting materials, including 12 samples (sample 72835-72854), with their precise depths are given in Table 1. The rocks show generally hyaline or aphanitic-to-porphyric texture. By necked eyes, the phenocrysts of the rocks include the main phases of quartz, muscovite, sericitized and saussuritized feldspars, feldspars, as well as the minor phases of tourmaline, chlorite, epidote, Fe-oxides, and carbonate. In general, the primary rhyolites were mostly altered similar to descriptions of Haneke (1987), Lippolt et al. (1989), von Seckendorf et al. (2004), and Aretz et al. (2015).

\section{Polarized-light microscopy (PM)}

Thin sections of representative rock samples from cutting materials of the altered porphyritic rhyolites were selected to examine petrographic properties using the PM at the HLUNG and the Technical Petrology Lab (Technical University of Darmstadt). These materials were the coarsest available cutting materials with the best-preserved structure and texture. Thus, in these rocks, mineralogical paragenetic information was possible to find. The results of this method allow defining the microscopic structure, the mineral texture, the rock alteration, and the newly formed minerals that can be served to study the mineralogical evolution of the rocks and the alteration reactions of primary minerals. Otherwise, this technique is limited for investigation of rocks with high clay content, so that XRF, XRD, FT-IR, and TEM methods were additionally applied.

\section{X-ray fluorescence (XRF)}

Bulk altered rhyolites were analyzed for chemical composition using a PANalytical AXIOS-Advanced Wavelength Dispersive X-ray Fluorescence (WDXRF) spectrometer and an SSTmAX-4-kW rhodium target X-ray tube equipped with laterally curved monochromators PX-10, LiF 220, InSb111, Ge111, PE002, PX-8, and PX-1 with the Geochemistry group (Georg August University of Göttingen). The samples were prepared as glass disks with a fully automated fusion technique. Loss on ignition (LOI) was determined at $1100{ }^{\circ} \mathrm{C}$ as an approximate measure of volatile $\mathrm{H}_{2} \mathrm{O}$. These data were characterized chemical composition of the bulk rocks and to cross-check the results of quantitative mineralogical composition identified by XRD of randomly oriented materials.

\section{X-ray diffraction (XRD)}

XRD was carried out to identify the semi-quantitative mineral composition and structure characteristics of each phase. The spectra of randomly oriented powders (bulk samples) and oriented mounts, which were saturated with deionized water and pipetting onto glass slides to get suspended $<2.0 \mu \mathrm{m}$ clay-fraction materials, were recorded by a Panalytical X'Pert Pro Diffractometer at Institute of Geosciences, Goethe University Frankfurt. The equipment was operated at $30 \mathrm{~mA}$ and $40 \mathrm{kV}, \mathrm{Cu}-\mathrm{K} \alpha_{1,2}$ radiation, $0.5 / 25$ soller collimator, automatic divergence slit, $\mathrm{X}^{\prime}$ Celerator line focus detector, and step size $0.008{ }^{\circ} 2 \theta$ with 20 total added seconds for each measurement step. The data were recorded in the range of $4-70^{\circ} 2 \theta$ for randomly oriented powder samples and $4-40^{\circ} 2 \theta$ for oriented mounts (air-dried and ethylene-glycolated specimens).

The main mineral components were identified by comparison with the ICDD/PDF-4 minerals database. The term "illite" is referred to the micaceous $\mathrm{CM}$ which is a slight departure from the $10 \AA d$ (001) reflection of illites defied by Brown (1961). In addition, the powder diffractograms of the bulk samples were processed by the BGMN-Rietveld software package developed by Bergmann et al. (1998). This program uses fundamental parameters for the refinement of the diffraction peak profiles to not only ordered minerals but also turbostratically disordered minerals like the smectite group as suggested by Ufer et al. (2010). The results from powder samples were also used to obtain the 060 reflection for interpreting the occurence of dioctahedral or trioctahedral sheet silicates.

The yielded spectra of oriented specimens were used to identify CM components and their changing behaviors of (001)-interferences (Starkey et al. 1984). The NEWMODbased comparison of interference positions from the (001)/ (002)- and (002)/(003)-reflections of Moore and Reynolds 
(1997) and Bethke et al. (1986) was also used to identify the percentage of smectitic layers in IS-ml. Consideration of size and strain effects, Origin Pro 8.5 Peak Fitting software package with the symmetric Gaussian distribution was used to fit the peak profiles then providing the $\mathrm{d}$ value, full width at half maximum (FWHM), and reflection intensity.

\section{Fourier transform infrared spectroscopy (FT-IR)}

Powder samples of approximately $1-2 \mathrm{mg}$ were mixed homogenously in $120 \mathrm{mg}$ of $\mathrm{KBr}$, which was predried at $80{ }^{\circ} \mathrm{C}$ for at least $6 \mathrm{~h}$, and then placed into a dye under pressure to form a pellet of $13 \mathrm{~mm}$ in diameter. The Varian 670-IR series FT-IR spectrometer at Technical University of Darmstadt (Dispersive Solids Lab, Institute of Material Sciences) was used for recording the spectra in the mid-infrared range, which extends from 400 to $4000 \mathrm{~cm}^{-1}$ with multiple scan (e.g., 64 scans and $4 \mathrm{~cm}^{-1}$ resolution), at room temperature. The FT-IR spectra were deconvoluted by Origin Pro 8.5 Peak Fitting. A Gaussian distribution function was applied to smooth the spectra and to provide the exact value of peak position, FWHM, intensity, and area. The interpretation of the absorption spectra followed mainly those given by Farmer (1974) and Farmer and Russel (1964).

\section{Transmission electron microscopy (TEM)}

For TEM analyses, powder samples were suspended in deionized water and dispersed by ultrasonic treatment for approximately $20 \mathrm{~min}$. The clay fraction $(<2.0 \mu \mathrm{m})$ was separated by sedimentation and diluted with deionized water to get the clear-look suspension. The suspension was dropped onto carbon-coated $\mathrm{Cu}$-grids, air-dried, and stored under environment-controlled conditions at $45 \%$ humidity. The TEM-image investigation was carried out using a TECNAI $\mathrm{G}^{2} 20$ transmission microscope (FEI) at the University of Science, Vietnam National University, Hanoi. This microscope combined with an S-TWIN objective and an FEI Eagle $2 \mathrm{k} \mathrm{CCD}$ camera was operated at $200 \mathrm{kV}$ with $\mathrm{LaB}_{6}$-cathode.

Individual clay particles with crystal size, crystal habit, and particle morphology were obsevered and characterized according to Henning and Störr (1986) and Sudo et al. (1981). The habit of particles found in the TEM-images could be used to support the quantitative calculation of ratios of expandable layers (\%S) in IS-ml (Inoue 1986) and to identify the polytype of micaceous minerals (Henning and Störr 1986). According to Inoue (1986), the appearance of IS-ml edge depends on the proportion of illitic layer. Pure illite or IS-R3 ( $2 M_{1}$ polytype) particles show a pseudo-hexagonal plate or idiomorphic sharp-edge morphology. Otherwise, xenomorphic plates and flakes together with subhedral and elongated particles correspond to randomly ordered IS-R0 $\left(1 M_{d}\right.$ polytype) and short-range ordered IS-R1 ( $1 M$ polytype).

\section{Results}

\section{Chemical, petrographical, and mineral compositions}

The highest chemical component of the altered rhyolite samples was identified as $\mathrm{SiO}_{2}$ with $53.3-57.0 \mathrm{wt} \%$ (Table 2). These amounts are significantly lower than those (>68 wt $\%$ ) of the typical primary rhyolites. The amounts of $\mathrm{Al}_{2} \mathrm{O}_{3}$ (19.5-22.6 wt\%, Table 2) is suitable for the expected richness of aluminosilicate minerals of such material. These amounts are app. $40 \%$ higher than the theoretical number for fresh rhyolites. Among the alkaline elements, $\mathrm{K}_{2} \mathrm{O}$ made up the higher proportion, which suggested the higher amount of $\mathrm{K}^{+}$in the feldspar group (orthoclase, sanidine) and the interlayer sheet of micaceous minerals. Comparing with the typical fresh rhyolites, the much higher $\mathrm{MgO}$ and $\mathrm{Fe}_{2} \mathrm{O}_{3}$ contents were from $\mathrm{Mg}$ - and/or Fe-bearing minerals, such as chlorite, Fe-oxides, dolomite, mica, and IS-ml (Mg and Fe may in octahedral sheets) phases, which were observed as phenocrysts and could be in the matrix component.

Under the PM, thin sections of the studied altered rhyolites showed aphanitic-to-porphyric texture with hypocrystalline structure (Fig. 2, Appendix). The glassy components include brown-to-white spherulites (Fig. 2f), which are typical for silica-rich rhyolites and result from an intergrowth of quartz and orthoclase. Many sections show the
Table 2 Chemical composition of bulk samples, determined by $\mathrm{XRF}(\mathrm{wt} \%)$

\begin{tabular}{llllllllllll}
\hline Sample & $\mathrm{SiO}_{2}$ & $\mathrm{TiO}_{2}$ & $\mathrm{Al}_{2} \mathrm{O}_{3}$ & $\mathrm{MnO}$ & $\mathrm{MgO}$ & $\mathrm{CaO}$ & $\mathrm{Na}_{2} \mathrm{O}$ & $\mathrm{K}_{2} \mathrm{O}$ & $\mathrm{P}_{2} \mathrm{O}_{5}$ & $\mathrm{Fe}_{2} \mathrm{O}_{3}$ & $\mathrm{LOI}$ \\
\hline 47969 & 53.34 & 0.22 & 19.54 & 0.05 & 3.12 & 2.42 & 0.99 & 6.43 & 0.07 & 4.79 & 8.89 \\
47970 & 53.23 & 0.17 & 20.93 & 0.03 & 3.22 & 1.36 & 0.94 & 6.92 & 0.06 & 5.06 & 7.74 \\
47971 & 57.02 & 0.26 & 19.78 & 0.04 & 3.56 & 1.01 & 1.33 & 6.50 & 0.08 & 4.17 & 6.03 \\
47972 & 56.67 & 0.21 & 19.51 & 0.03 & 3.02 & 2.05 & 1.27 & 6.51 & 0.07 & 4.01 & 6.36 \\
47973 & 54.83 & 0.14 & 21.89 & 0.04 & 3.56 & 1.16 & 0.98 & 7.22 & 0.05 & 3.14 & 6.80 \\
47974 & 54.06 & 0.13 & 21.68 & 0.05 & 3.25 & 1.56 & 0.98 & 7.16 & 0.04 & 3.17 & 7.32 \\
47975 & 55.53 & 0.13 & 21.42 & 0.04 & 3.14 & 0.89 & 1.18 & 7.10 & 0.05 & 3.09 & 6.73 \\
47976 & 56.74 & 0.05 & 22.69 & 0.04 & 3.05 & 0.58 & 1.87 & 7.09 & 0.10 & 1.69 & 5.73 \\
\hline
\end{tabular}


Fig. 2 Microscopic observation of thin sections at different depths of geothermal borehole samples. $Q t z$ quartz, $B t$ biotite, $M u$ muscovite, $M s$ mica, $C h l$ chlorite, ill illite, Fsp feldspars, Ser Fsp sericized feldspars, Plag plagioclase, Ortho orthoclase, $C c$ carbonate minerals (in the XRD study detected as dolomite), Ep epidote. (I) sheets of $\mathrm{Chl}$ bedded in fine grain mica and quartz, (II) growth of micro- $\mathrm{SiO}_{2}$, illite and $\mathrm{Fe}-$ chlorite on glassy matrix, and (III) growth of illite on glassy matrix. Sample 72836 shows reaction structural fabrics at transmitted light, and all other samples are shown under polarized light
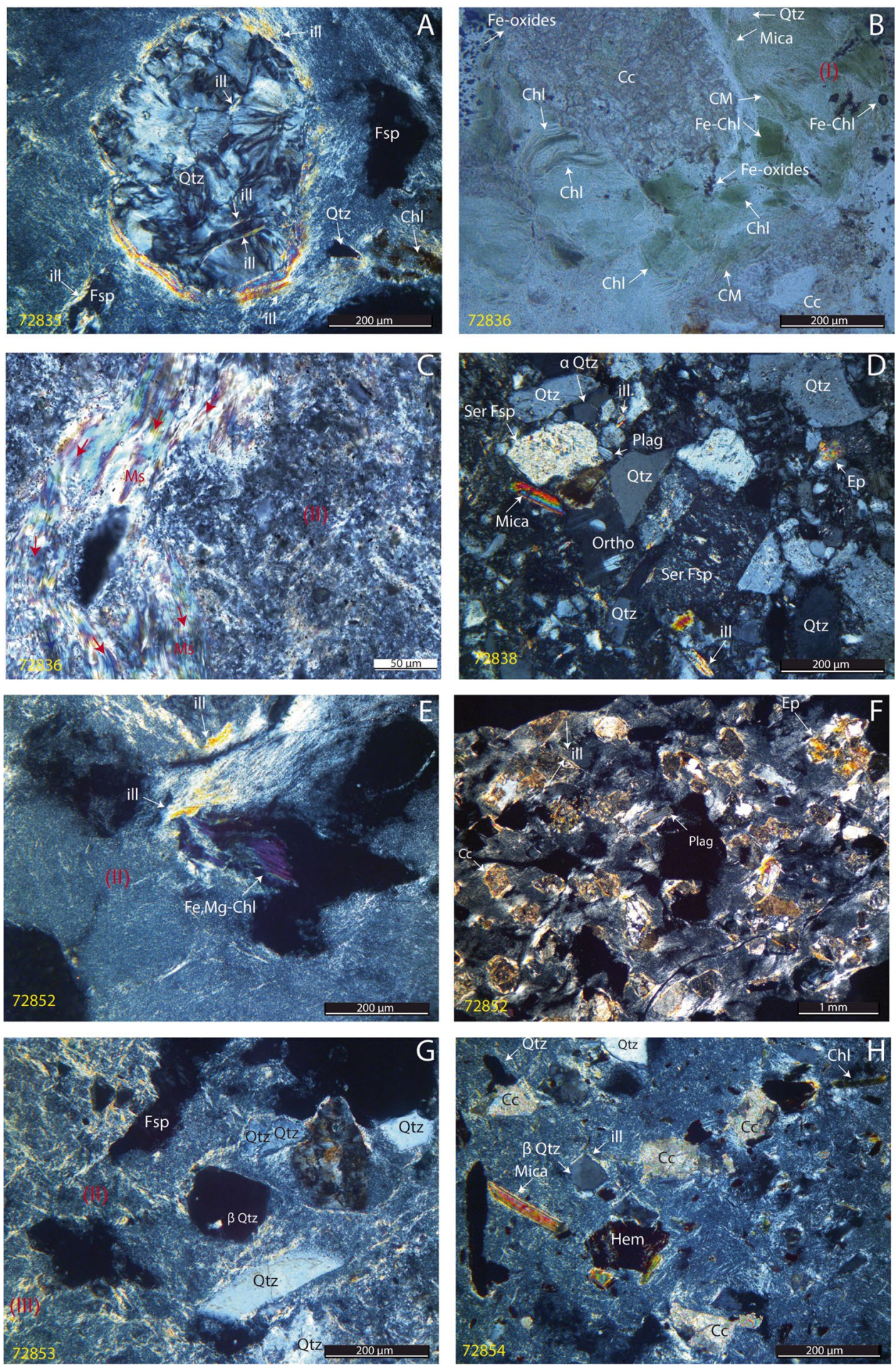

growth of microcrystals of illite (Fig. 2g) or quartz + illite/ muscovite $+\mathrm{Fe}$-chlorite on the matrix (Fig. 2c, e, g), which demonstrates the happened alteration process. Even illite/muscovite showing hydrothermal-flow structure was frequently observed (Fig. 2c). The identified crystalline components include altered feldspars, primary feldspars, mica, quartz, and some minor and trace phases, which are quite similar to the observation by necked eyes with the raw samples (Table 1). The mineral composition of the bulk samples was confirmed and quantified by XRD analysis and BGMN-Rietveld refinement (Fig. 3, Table 3). The main phases were aslo clarified by the FT-IR technique due to their molecular vibration (Fig. 4, Table 4). 
Fig. 3 Representative XRD pattern of bulk sample 72853 ( $3735 \mathrm{~m})$ refined by BGMNRietveld software. Legend: dots-experimental XRD-data, solid back line-refined XRDdata, solid blue line-background, solid red line-difference between experimental and refined XRD-data and Rwp and 1-rho-accuracy of refinement

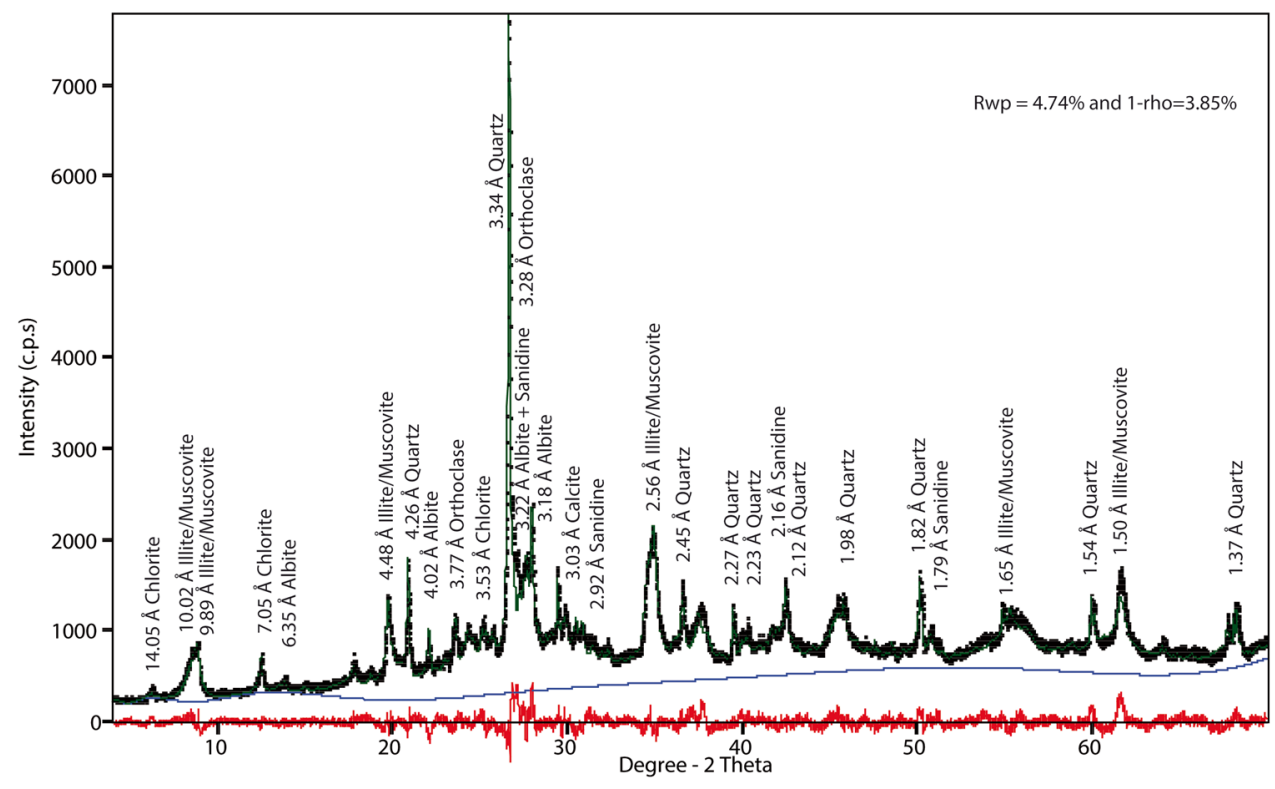

Table 3 Mineralogical composition (wt \%) of bulk samples, determined from XRD data with the BGMN-Rietveld software

\begin{tabular}{lllllllllllllllll}
\hline Mineral & 47969 & 47970 & 47971 & 47972 & 47973 & 47974 & 47975 & 47976 & 72843 & 72844 & 72845 & 72846 & 72851 & 72852 & 72853 & 72854 \\
\hline Quartz & 7.5 & 4.2 & 5.8 & 5.3 & 6.0 & 8.8 & 7.2 & 3.0 & 25.4 & 5.9 & 15.6 & 9.3 & 7.1 & 11.8 & 8.9 & 14.8 \\
Orthoclase & - & 1.6 & 2.0 & 2.1 & 2.3 & 4.1 & 2.3 & 2.8 & 14.8 & 6.0 & 8.5 & 6.2 & 4.6 & 6.0 & 3.9 & 4.9 \\
Sanidine & 2.4 & 2.5 & 3.1 & 3.1 & 2.43 & 3.4 & 2.8 & 3.9 & 6.3 & 7.0 & 11.8 & 11.2 & 5.0 & 8.7 & 4.4 & 4.6 \\
Albite & 3.1 & 2.4 & 4.1 & 4.2 & 3.0 & 5.4 & 4.6 & 4.9 & 7.9 & 5.0 & 18.2 & 6.9 & 23.4 & 5.9 & 7.3 & 6.9 \\
Illite & 4.5 & 4.0 & 4.7 & 3.0 & 14.7 & 18.2 & 2.7 & 3.89 & 4.0 & 12.2 & 8.6 & 14.5 & 8.1 & 29.6 & 2.9 & 17.5 \\
Muscovite $2 M_{l}$ & 12.5 & 21.4 & 20.1 & 23.1 & 23.4 & 7.5 & 21.0 & 27.7 & 7.7 & 26.2 & 14.7 & 23.3 & 37.1 & 8.5 & 35.9 & 4.0 \\
Muscovite $1 M$ & 61.0 & 59.6 & 56.1 & 52.2 & 43.0 & 43.1 & 55.4 & 50.4 & 33.9 & 31.3 & 14.8 & 17.3 & 10.2 & 19.7 & 29.4 & 33.5 \\
Chlorite & 3.9 & $<1$ & 2.0 & 4.2 & 1.6 & 1.9 & 2.5 & 2.0 & - & 5.9 & 4.9 & 7.8 & 4.5 & 8.8 & 6.4 & 10.2 \\
Hematite & 1.8 & 1.6 & - & $<1$ & & $<1$ & $<1$ & $<1$ & - & - & 1.7 & 2.2 & - & - & - & - \\
Calcite & 2.2 & 1.2 & $<1$ & 1.9 & $<1$ & 1.5 & - & & - & $<1$ & 1.3 & 1.3 & - & 1.0 & $<1$ & 3.8 \\
Dolomite & $<1$ & $<1$ & $<1$ & - & 1.4 & 2.8 & - & & - & - & - & - & - & - & - & - \\
\hline
\end{tabular}

Iron contents from the sample holders varied between $<1 \div 3.1$ with the samples $47969 \div 47976$, and could not be detected with other samples

K-feldspar, including sanidine and perthitic orthoclase, as well as albite were found from the studied samples by both PM and XRD methods. The BGMN-Rietveld refinement determined 3 members of feldspars, including orthoclase, sanidine, and albite, with the total proportions ranging from 5.5 to $38.5 \mathrm{wt} \%$ (Fig. 3, Table 3), which is much lower than that of normal fresh rhyolites. The orthoclase/(sanidine + albite) ratio reached the maximal value of $\sim 1$ (sample 72843), while potassium feldspar of primary rhyolites is known presenting in at least twice the amount of plagioclase. Due to the low amount, only weak bending bands $\sim 727 \mathrm{~cm}^{-1}$ for $\mathrm{AlO}$ and $\sim 1010 \mathrm{~cm}^{-1}$ for $\mathrm{SiO}$ of orthoclase could be verified for some samples, such as sample 72843 (with the highest amount of orthoclase) (follows the description of Xue et al. 2019). Some fresh feldspars, such as particles in Fig. 2a, g, orthoclase in Fig. 2d, perthitic orthoclase, and idiomorphic sanidine, have remained. However, most of the feldspars were altered by sericitization and saussuritization processes. Sericitized feldspars formed by the conversion of feldspars into microcrystals of illite or sericite are shown in Fig. 2a, d, f. Saussuritized plagioclase was observed with the presenting of carbonate, chlorite, and CMs in Fig. $2 b$.

Mica (biotite, muscovite, and illite) identified by PM shows 3 grain-sizes, including $\sim 5 \mathrm{~m}$ grain as coating and filling veins in quartz and feldspars (Fig. 2a, b), 10-20 $\mu \mathrm{m}$ aggregation of subhedral particles (Fig. $2 \mathrm{a}, \mathrm{c}, \mathrm{e}$ ), and $>50 \mu \mathrm{m}$ idiomorphic or subhedral particles (Fig. 2b, d, e, h). Biotite, the typical mica member of primary rhyolite, was found (Fig. 2d, h) but with low frequency. In particular, some particles show neo-formation of illite, but some others show no trace of the alteration in the same section (Fig. 2d). In the XRD diffractograms, an asymmetric peak around $10 \AA$ could 
Fig. 4 FT-IR spectra of three representative bulk rock samples (47972 at 3615-3745 m; 72843 at $3725 \mathrm{~m}$, and 72851 at $3735 \mathrm{~m})$
Table 4 FT-IR absorption values for IS-ml phases (in wavenumber frequencies $\mathrm{cm}^{-1}$ )

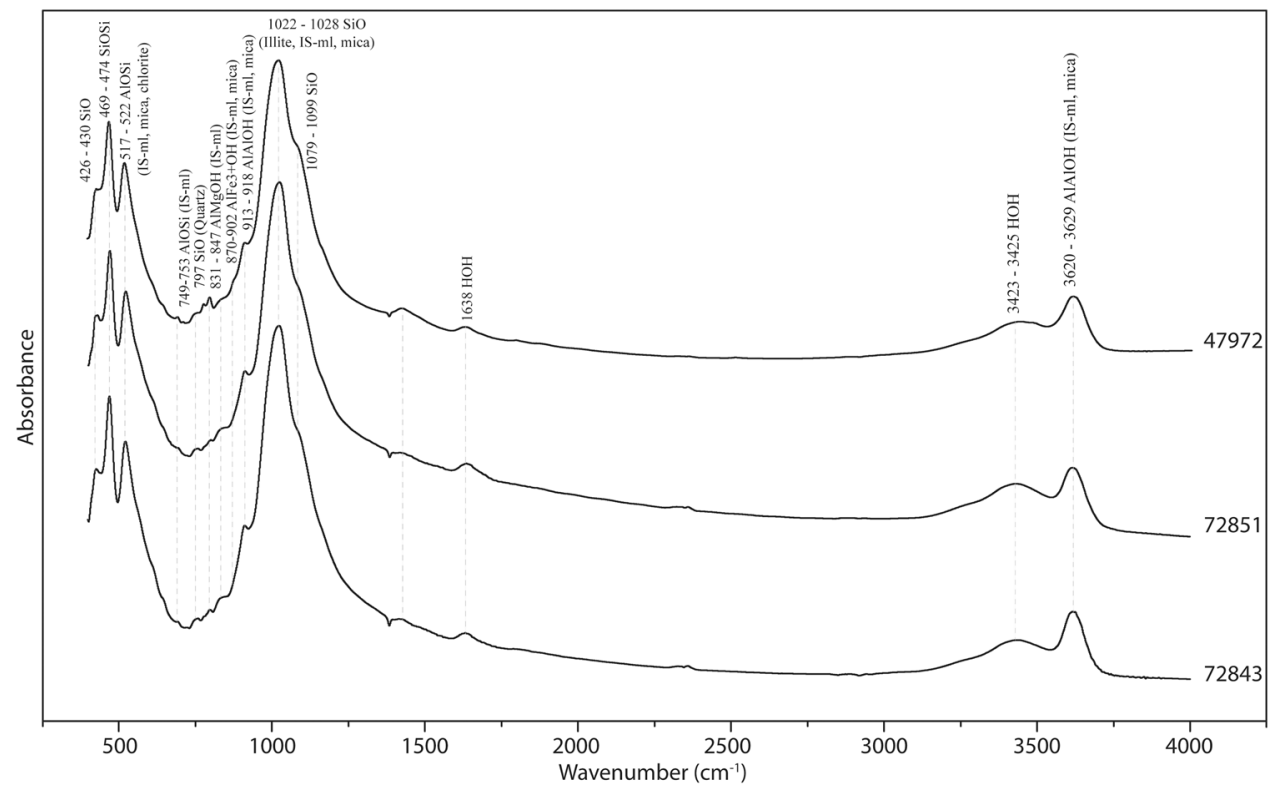

\begin{tabular}{llllllllll}
\hline Sample & $\mathrm{AlAlOH}$ & $\mathrm{SiO}$ & $\mathrm{AlAlOH}$ & $\mathrm{AlFe}^{3+} \mathrm{OH}$ & $\mathrm{AlMgOH}$ & $\mathrm{AlOSi}$ & $\mathrm{AlOSi}$ & $\mathrm{SiOSi}$ & $\mathrm{SiO}$ \\
\hline 47969 & 3618 & 1026 & 914 & 872 & 847 & 751 & 520 & 470 & 426 \\
47970 & 3618 & 1025 & 917 & 871 & 831 & 750 & 520 & 470 & 429 \\
47971 & 3614 & 1024 & 915 & 899 & 840 & 749 & 518 & 471 & 428 \\
47972 & 3620 & 1022 & 913 & 873 & 845 & 750 & 520 & 473 & 427 \\
47973 & 3620 & 1027 & 915 & 872 & 840 & 751 & 520 & 469 & 427 \\
47974 & 3616 & 1025 & 918 & 883 & 832 & 752 & 522 & 470 & 427 \\
47975 & 3628 & 1026 & 914 & 865 & 833 & 751 & 521 & 471 & 423 \\
47976 & 3617 & 1025 & 916 & 895 & 837 & 753 & 522 & 471 & 427 \\
72843 & 3618 & 1026 & 913 & 902 & 835 & 752 & 522 & 472 & 427 \\
72844 & 3613 & 1025 & 913 & 873 & 842 & 749 & 521 & 474 & 430 \\
72845 & 3612 & 1024 & 914 & 883 & 834 & 750 & 520 & 473 & 429 \\
72846 & 3620 & 1026 & 917 & 890 & 832 & 750 & 521 & 471 & 423 \\
72851 & 3622 & 1023 & 913 & 895 & 834 & 751 & 521 & 473 & 425 \\
72853 & 3620 & 1025 & 915 & 895 & 833 & 750 & 517 & 473 & 426 \\
\hline
\end{tabular}

be deconvoluted into two peaks with $d(001)=9.89-10.1 \AA$ and 10.3-10.5 $\AA$. With BGMN-Rietveld refinement, the research could define 3 different phases, including illite, muscovite $2 M_{1}$, and muscovite $1 M$ of the micaceous minerals, which made up the highest proportions ( $38-85 \mathrm{wt} \%$, Table 3). Low-intensity peaks at 3.06-3.09 ̊ (not shown) were specified exclusively for muscovite $1 M$ polytype. The occurrence of the micaceous phases as the only dioctahedral CMs that could be found in the studied materials was confirmed by $d$ (060) at $1.50 \AA$ (Fig. 3). The highest proportions of mica (IS-ml and illite/muscovite) were the reason for all of the significant FT-IR vibration bands that belong to their different bondings. Based on the descriptions of Farmer (1974), Farmer and Russell (1967), Goodman et al. (1976), Madejová and Komadel (2001), Bishop et al. (2002), and Seki and Yurdakoç (2007) as well as the yielded FT-IR spectra (Fig. 4), the IS-ml and mica phases were detected in all of the studied samples with $\mathrm{AlAlOH}$ stretching, $\mathrm{SiO}$ stretching, $\mathrm{AlAlOH}$ bending, $\mathrm{AlFe}^{3+} \mathrm{OH}$ bending, $\mathrm{AlMgOH}$ bending, AlOSi in-plane, AlOSi deformation, SiOSi deformation, and $\mathrm{SiO}$ deformation bands in the decreasing order of the absorption values (Table 4). In general, by LM, XRD, and FT-IR methods, mica was identified as the dominant part of the studied altered rhyolites and included three different phases with different grain-sizes and morphologies. However, most of the mica phase showed the alteration footprint: (1) as the secondary generation from feldspars, and (2) as the former generation of chlorite-muscovite stacks (Fig. 2e).

Chlorite made up small proportions, but could reach to up $10.2 \mathrm{wt} \%$ (sample 72854, $3735 \mathrm{~m}$ deep). Three populations 
of chlorite, which were frequently observed correspondingly to the three mentioned grain-sizes of mica, include: $\sim 50 \mu \mathrm{m}$ flakes grew tightly with fine mica, $\sim 50-70 \mu \mathrm{m}$ aggregations of subhedral particles, and $\sim 10-150 \mu \mathrm{m}$ of $\mathrm{Fe}, \mathrm{Mg}$-chlorite growing on biotite (Fig. 2b, e). The sign of chlorite, in the FT-IR spectra, could share with mica at AlOSi deformation band around $517-522 \mathrm{~cm}^{-1}$.

Quartz can be observed by FT-IR with the $\sim 1079-1099 \mathrm{~cm}^{-1} \mathrm{SiO}$ stretching (mentioned by van der Marel and Beutelspacher 1976) and $797 \mathrm{~cm}^{-1} \mathrm{SiOSi}$ bending (mentioned by Vantelon et al. 2001) (Fig. 4) and by PM in both species: $\alpha$-quartz (Fig. $2 \mathrm{~d}$ ) and $\beta$-quartz (Fig. $2 \mathrm{~g}, \mathrm{~h}$ ). The mineral was quantified from XRD data with 3.0-25.4 wt\% (Table 3), which is much lower than that of normal fresh rhyolites. Epidote (grew on plagioclase, Fig. 2d, f), tourmaline, and garnet (not shown) were identified as trace phases similar to the composition of phenocrysts (Table 1). Fe-oxides (Fig. 2b) or hematite made up a small amount to $2.2 \mathrm{wt} \%$. In particular, the carbonate phases including both calcite and dolomite, uncommon constituent for primary rhyolites, are widespread in the studied samples with the total mount reaching to $4.3 \mathrm{wt} \%$ (Fig. 2b, h, Table 3).

\section{Structure of clay minerals}

The detailed structures of CMs, including dominant IS-ml and end-members, were carried out by XRD and TEM analyses with the clay-fraction samples. Both results verified that the CMs in the altered rhyolites include different phases of IS-ml and end-members with different orders and polytypes (Table 5, Figs. 5, 6). The results also show an agreement with the found CMs in the bulk samples.

Using Origin 8.5 Peak Fitting and NEWMOD-based comparison of interference positions for the asymmetric peak around $10 \AA$, this research found 4 phases related to IS-ml and end-members (Fig. 5). The first and second phases presented $d$ (001) ranging from 10.07 to $12.08 \AA$ in the XRD curves of air-dried specimens, then shifting to $10.54-12.31 \AA$ (with FWHM $0.55-1.37$ ) or only 10.01-10.26 ̊ (with FWHM 0.12-0.85) when ethyleneglycolate saturation. These shifting steps indicated for IS-R1 with smectitic proportion (\%S) of 15-40, and IS-R3 with $\% S<10$, respectively. The third phase was found with unchanged $d$ (001) around 9.64-10.04 $\AA$ between the airdried and ethylene-glycolated specimens. Pure illite/muscovite with the IS-R3 polytype and no smectitic layer should be the reason for this behavior. In some samples at the lower depths, including 47971, 47972, and 47973, there were low intensity peaks with $d(001)$ in the range $12.54-14.57 \AA$ from air-dried specimens and correspondingly 16.53-17.24 from ethylene-glycolated ones. The information allows identifying the fourth phase end-member smectite $\% S=90-100$ or IS-R0 with possible dominated $\mathrm{Na}^{+}$in the interlayer sheet. This phase could not identify in the XRD patterns of the powders, because of the very low amount in the bulk samples. Besides the dominant IS-ml and end-members, all of the investigated samples contain small amounts of chlorite, which showed reflections $\sim 14 \AA$ and $\sim 7 \AA$ in oriented XRD patterns similar to power XRD ones.

Under TEM observation, a powerful technique for microscale objects, particles of CMs could be identified and classified into 3 groups based on different morphologies, habitat, and orders (follows the description of Henning and Störr 1986; Inoue 1986). The first group includes the aggregation of subhedral or elongated particles and medium-large plates with size $\sim 0.5-1.5 \mu \mathrm{m}$, which can contain an amount of expandable smectitic proportion $<40 \%$. Both types of morphologies in the group can be observed abundantly in sample 47970 (Fig. 6A1-A3) or less with sample 47971 (Fig. 6B1, B2). With other samples, the elongated ones are seldom, but the plates are often (sample 47972: Fig. 6C2, sample 72853: Fig. 6D1-D3, sample 72844: not shown). This group was specified as IS-R1 with $1 M$ polytype. The second group was indicated to disaggregation of sharp-edge (idiomorphic) laths and pseudo-hexagonal small-to-large $(1-2 \mu \mathrm{m})$ plates. The phases show nearly no expandable sign. The clay particles that fall in this group could find from all of the samples (Fig. 6A3, B1, B2, C1-C3, D3). The long-range ordered mica (IS-R3) with $2 M_{1}$ polytype was allocated for this second group. The other particles were pointed to the group of aggregation of small $(<0.5 \mu \mathrm{m})$ xenomorphic plates and flakes, which showed the high expandability. Only few slides could show these mophologies (Fig. 6B3, C2, D1-D3). Endmember smectite (IS-R0) with $1 M_{d}$ polytype was assigned for the low amount of the third group.

Conclusions, in agreement between both XRD and TEM analyses, the CMs of the altered rhyolites include 2 types of IS-ml: IS-R1 $1 M$ with $\% S=15-40$ and IS-R3 $2 M_{1}$ with $\% S<10$, end-member illite/muscovite IS-R3 $2 M_{1}$, and small amount of end-member smectite IS-R0 $1 M_{d}$. Besides the dominant IS-ml and end-members, the CMs of the studied materials also include chlorite.

\section{Discussion}

\section{Temperature of transfomation}

As a part of the European Cenozoic Rift system, URG is characterized by a variety of tectonic activities linked with several hydrothermal pulses (Gaupp et al. 1993). The geodynamic regime affects mineral formation, especially CMs. The coexisting of IS-ml and end-members with all three IS-R0, IS-R1, and IS-R3 orders in the studied altered rhyolites cannot be explained with a syngenetic formation and 
Table 5 Ordering structure of IS-ml and end-members obtained from XRD results of oriented specimens by deconvolution using Origin 8.5 peak fitting

\begin{tabular}{|c|c|c|c|c|c|c|}
\hline \multirow[t]{2}{*}{ Samples } & \multicolumn{2}{|l|}{ Air-dried } & \multicolumn{2}{|c|}{ Ethylene-glycolated } & \multirow[t]{2}{*}{$\% S$} & \multirow[t]{2}{*}{ Reichweite (R) } \\
\hline & $d$ value $(\AA)$ & FWHM $\left(\Delta^{\circ} 2 \theta\right)$ & $d$ value $(\AA)$ & $\mathrm{FWHM}\left(\Delta^{\circ} 2 \theta\right)$ & & \\
\hline \multirow[t]{3}{*}{47969} & 10.73 & 1.30 & 11.63 & 1.30 & $20-25$ & IS-R1 \\
\hline & & & 10.26 & 1.37 & $<10$ & IS-R3 \\
\hline & 10.04 & 0.60 & 9.99 & 0.49 & 0 & Illite (IS-R3) \\
\hline \multirow[t]{2}{*}{47970} & 10.07 & 0.95 & 10.55 & 1.04 & 15 & IS-R1 \\
\hline & 10.03 & 0.79 & 9.96 & 0.51 & 0 & Illite (IS-R3) \\
\hline \multirow[t]{3}{*}{47971} & 14.57 & 0.88 & 16.53 & 0.59 & $90-100$ & Smectite (IS-R0) \\
\hline & 10.36 & 1.47 & 10.71 & 1.30 & 20 & IS-R1 \\
\hline & & & 9.90 & 0.66 & 0 & Illite (IS-R3) \\
\hline \multirow[t]{3}{*}{47972} & 12.71 & 0.86 & 17.24 & 0.59 & $90-100$ & Smectite (IS-R0) \\
\hline & 10.69 & 0.68 & 11.20 & 1.07 & 30 & IS-R1 \\
\hline & 9.90 & 0.73 & 9.98 & 0.85 & 0 & Illite (IS-R3) \\
\hline \multirow[t]{5}{*}{47973} & 12.54 & 0.92 & 16.73 & 0.26 & $90-100$ & Smectite (IS-R0) \\
\hline & 11.05 & 0.78 & 12.24 & 0.55 & $35-40$ & IS-R1 \\
\hline & 10.32 & 0.65 & 11.36 & 1.11 & $>30$ & IS-R1 \\
\hline & 10.14 & 1.01 & 10.65 & 1.28 & 20 & IS-R1 \\
\hline & & & 9.89 & 0.72 & 0 & Illite (IS-R3) \\
\hline \multirow[t]{3}{*}{47974} & 11.10 & 0.99 & 11.80 & 0.92 & 35 & IS-R1 \\
\hline & 10.32 & 0.73 & 10.77 & 0.85 & $>20$ & IS-R1 \\
\hline & 10.0 & 0.56 & 9.90 & 0.70 & 0 & Illite (IS-R3) \\
\hline \multirow[t]{3}{*}{47975} & 11.46 & 0.79 & 11.78 & 1.05 & $<35$ & IS-R1 \\
\hline & 10.36 & 0.78 & 10.54 & 1.08 & 15 & IS-R1 \\
\hline & 10.03 & 0.54 & 9.93 & 0.60 & 0 & Illite (IS-R3) \\
\hline \multirow[t]{4}{*}{47976} & 11.12 & 0.96 & 11.77 & 0.62 & $<35$ & IS-R1 \\
\hline & 10.40 & 0.65 & 11.05 & 0.77 & 20 & IS-R1 \\
\hline & & & 10.12 & 0.78 & $<10$ & IS-R3 \\
\hline & 9.68 & 0.62 & 9.91 & 0.57 & 0 & Illite (IS-R3) \\
\hline \multirow[t]{3}{*}{72843} & 10.41 & 0.74 & 10.85 & 1.25 & $>20$ & IS-R1 \\
\hline & 9.92 & 0.65 & 9.95 & 0.66 & 0 & Illite (IS-R3) \\
\hline & & & 9.93 & 0.69 & 0 & Illite (IS-R3) \\
\hline \multirow[t]{4}{*}{72844} & 11.21 & 1.16 & 12.18 & 1.13 & $25-30$ & IS-R1 \\
\hline & 10.46 & 0.72 & 11.06 & 1.02 & 20 & IS-R1 \\
\hline & & & 10.01 & 0.72 & $<10$ & IS-R3 \\
\hline & 9.64 & 0.65 & 9.89 & 0.63 & 0 & Illite (IS-R3) \\
\hline \multirow[t]{4}{*}{72845} & 11.00 & 0.70 & 11.27 & 1.37 & $>20$ & IS-R1 \\
\hline & 10.36 & 0.70 & 10.76 & 1.32 & $>20$ & IS-R1 \\
\hline & 9.98 & 0.13 & 9.98 & 0.12 & 0 & Illite (IS-R3) \\
\hline & 9.52 & 0.93 & 9.86 & 0.79 & 0 & Illite (IS-R3) \\
\hline \multirow[t]{3}{*}{72846} & 10.49 & 1.37 & 10.89 & 1.34 & $<20$ & IS-R1 \\
\hline & 9.99 & 0.58 & 9.98 & 0.61 & 0 & Illite (IS-R3) \\
\hline & 9.65 & 0.50 & 9.87 & 0.45 & 0 & Illite (IS-R3) \\
\hline \multirow[t]{3}{*}{72851} & 12.08 & 0.79 & 12.31 & 0.89 & $25-30$ & IS-R1 \\
\hline & 10.78 & 1.25 & 10.99 & 1.14 & 20 & IS-R1 \\
\hline & 9.77 & 0.78 & 9.88 & 0.74 & 0 & Illite (IS-R3) \\
\hline \multirow[t]{3}{*}{72852} & 11.31 & 0.78 & 12.08 & 0.79 & $>35$ & IS-R1 \\
\hline & 10.44 & 0.71 & 10.78 & 1.25 & $<20$ & IS-R1 \\
\hline & 9.78 & 0.69 & 9.87 & 0.77 & 0 & Illite (IS-R3) \\
\hline
\end{tabular}



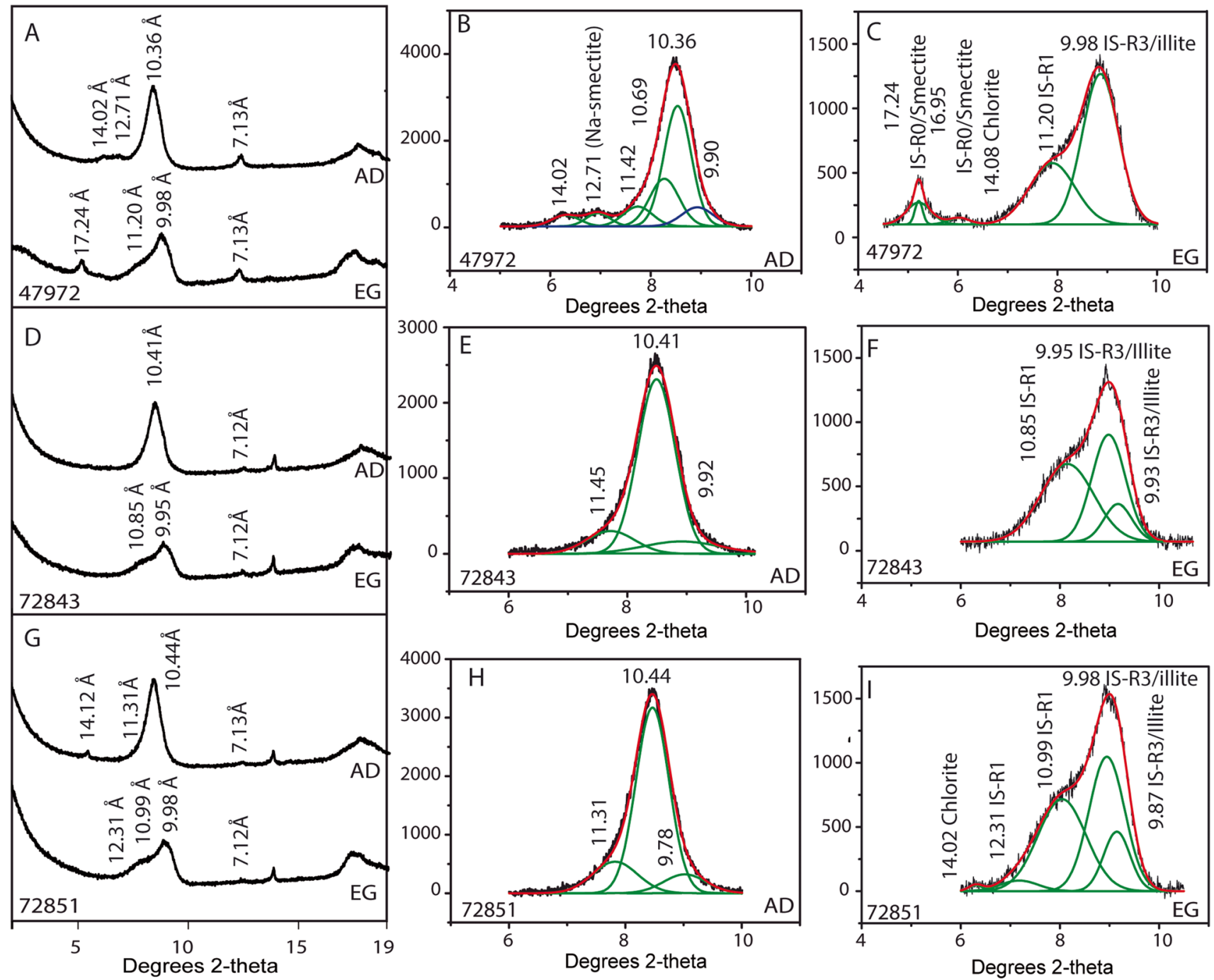

Fig. 5 XRD patterns of three selected samples with clay fraction of air-dried specimen (AD) and ethylene-glycolated specimen (EG). Deconvolution of (001) peak showing the experimental lines (black), the best fits (red), and elementary Gaussian curves (green)

suggest a complex evolution. Our research is not included the geological time criterion (because of no radiometric ages and stratigraphic markers), so that the affecting temperature is estimated based on the transformation between phases, especially transformation of smectite to illite (smectitie illitization). Ramseyer and Boles (1986) also mentioned that temperature should be considered as the main factor controlling the rate of hydrothermal system. Based on the geological setting and geothermal system (chapter 2) as well as the overviewing of temperature affecting IS-ml struture (chapter 1.2), different temperature milestones are now pointed out for the mineral transformation.

The temperature during the magma cooling is approximately $400-200{ }^{\circ} \mathrm{C}$, in which primary mica formed during magmatic state at around $350{ }^{\circ} \mathrm{C}$ (Yoder and Eugster 1955; Velde 1965, Christidis 1995). The transformation of feldspars and muscovite into secondary phases from the Soultz-sous-Forêts rhyolites at late magmatic temperatures of $>200{ }^{\circ} \mathrm{C}$ was stated by Dubois et al. (1996). Because of the missing Mesozoic strata, the area was lifted at the surface with significantly low temperature $\left(\sim 25^{\circ} \mathrm{C}\right.$ as atmospheric temperature).

Northern URG area suffers from geothermal systems through the faults and fracture zone (as observed in Standenbühl Formation, Donnersberg Formation, Miocene Wiesbaden Formation). The still existing discrete smectite phase demonstrates that the hydrothermal system limits at $\sim 230^{\circ} \mathrm{C}$. Moreover, the epidote growth on feldspars (Fig. 2d, f) indicated a mean temperature of $200-220{ }^{\circ} \mathrm{C}$ in geothermal systems for an association of epidote + albite $+\mathrm{K}$-feldspar + mica + quartz observed very often in rhyolites and intermediate volcanic rocks (Seki 1972; Bird and Helgeson 
Fig. 6 TEM images of some selected samples from geothermal borehole
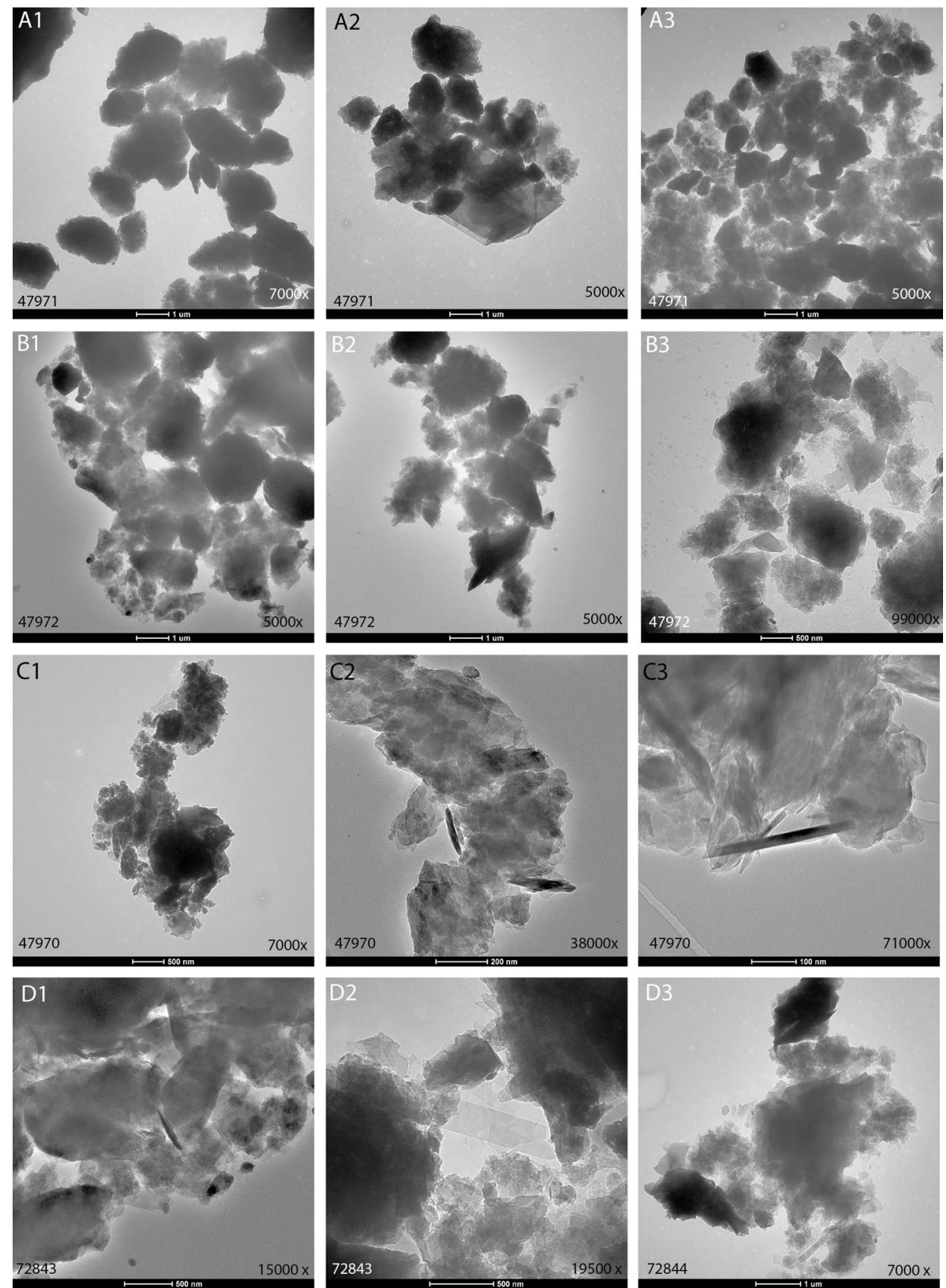

1981; Rochelle et al. 1989; Frey 1987). However, during the contact metamorphisms, the peak of hydrothermal temperature should be higher than $170{ }^{\circ} \mathrm{C}$, corresponding to the minimum temperature of IS-R1 and IS-R3 transformation.

IS-ml phase, observed by PM as neo-formation directly from primary mica (Fig. 2d) and by TEM as medium-large plates with IS-R1 structure, indicated that transformation from IS-R3 to IS-R1 happened during the evolution. Therefore, the beginning of hydrothermal alteration happened at lower than $170{ }^{\circ} \mathrm{C}$. The IS-R 1 phase, identified with the KI (FWHM $\sim 1.0 \Delta^{\circ} 2 \theta$ ) (Table 5), could be formed at a higher temperature than $100{ }^{\circ} \mathrm{C}$ reported by Harvey and Browne (1991), Merriman and Kemp (1996), and Merriman and Frey (1999). Aquilina et al. (1997) studied water-rock interaction processes in URG also found $1 M$ polytype formed purely in hydrothermal condition at a lower temperature $\left(130-170{ }^{\circ} \mathrm{C}\right)$ as a consequence of mixture between old and young brines in comparison with $2 M_{1}$ polytype $\left(>200{ }^{\circ} \mathrm{C}\right)$. Inoue et al. (2004) found the same result about the transformation of felsic volcanic clastic rocks in the Kakkonda geothermal system (Japan) under the circulation of NaClrich brine into elongated $1 M$ polytype of illite (IS-R1) at the 
temperature of $133-160{ }^{\circ} \mathrm{C}$. Furthermore, the found IS-ml phase with $\% S=15-40$ (Table 5) could be formed with a higher temperature than the temperature $110-135{ }^{\circ} \mathrm{C}$ to form IS-ml with $\% S>50 \%$ in the studies of Muffler and White (1969), and Harvey and Browne (1991). Not only CMs but also dolomite found in the studied material (XRD result, Table 3) can be used as a temperature sign. Boiron et al. (2010) and Dezayes and Lerouge (2019) stated that dolomite is likely precipitated from hydrothermal fluids with a high amount of meteoric water at about $130-150{ }^{\circ} \mathrm{C}$; therefore, the relatively lower temperature period to form IS-ml or $1 M$ polytype from 140 to $170{ }^{\circ} \mathrm{C}$.

The later mineral transformation in Cenozoic time mostly belongs to the hydrothermal gradient, which is estimated consistent with the temperature $\left(130^{\circ} \mathrm{C}\right)$ of the present-day geothermal sites. This temperature also fits with the presence of the dominant $1 M$ phase in the studied material.

To sum up, six stages could be drawn out for the studied material evolution: (1) The rhyolites were born in Permian time, near the surface, and then cooled from $<400$ to $\sim 200{ }^{\circ} \mathrm{C}$; (2) the area was lifted and was eroded overburden at the surface. At these times, the materials were also altered by the cooling process and possible hydrothermal fluid; (3) the rhyolites met hot fluids and suffered contact metamorphisms. The studied material was strongly altered by hydrothermal alteration with temperatures of $140-170{ }^{\circ} \mathrm{C}$; (4) the area was under subsidence with the possible formation of Mesozoic sediment. The studied material was continuously altered by hydrothermal alteration and burial diagenesis. The temperature was higher than $170{ }^{\circ} \mathrm{C}$ and could be reached a maximum of $\sim 230{ }^{\circ} \mathrm{C}$ at this stage; (5) the area was lifted and suffered the exhumation, resulting in late Cretaceous $2500 \mathrm{~m}$ eroded. The studied material was under a much lower gradient temperature, but still kept up with the $\sim 130{ }^{\circ} \mathrm{C}$ hydrothermal affection; (6) the area was under Cenozoic subsidence and compaction. The studied material was relatively stable with the hydrothermal process.

During the six stages, the transformation of minerals, especially the clay phases, can be grouped into three transformation processes: (1) alteration during magma cooling and possible contact metamorphisms with decreasing and low temperature-stages $1+2$; (2) alteration by burial diagenesis and hydrothermal alteration with significant increasing temperature-stages $3+4$; (3) transformation under exhumation and Cenozoic subsidence with decreasing temperaturestages $5+6$. The following parts will discuss the CM formations, including the order, structure, and composition; as well as the transformation mechanism. The summary is shown in Fig. 7.

\section{Smectitization during magma cooling}

With the observed mineral composition of the studied rhyolite, only a few fresh feldspars and mica as phenocrysts remained; the others showed altered signs and neo-formations, such as sericitized feldspars, saussuritized plagioclase, illite/muscovite with hydrothermal-flow structure, and growth of epidote on plagioclase. Normally, the fresh

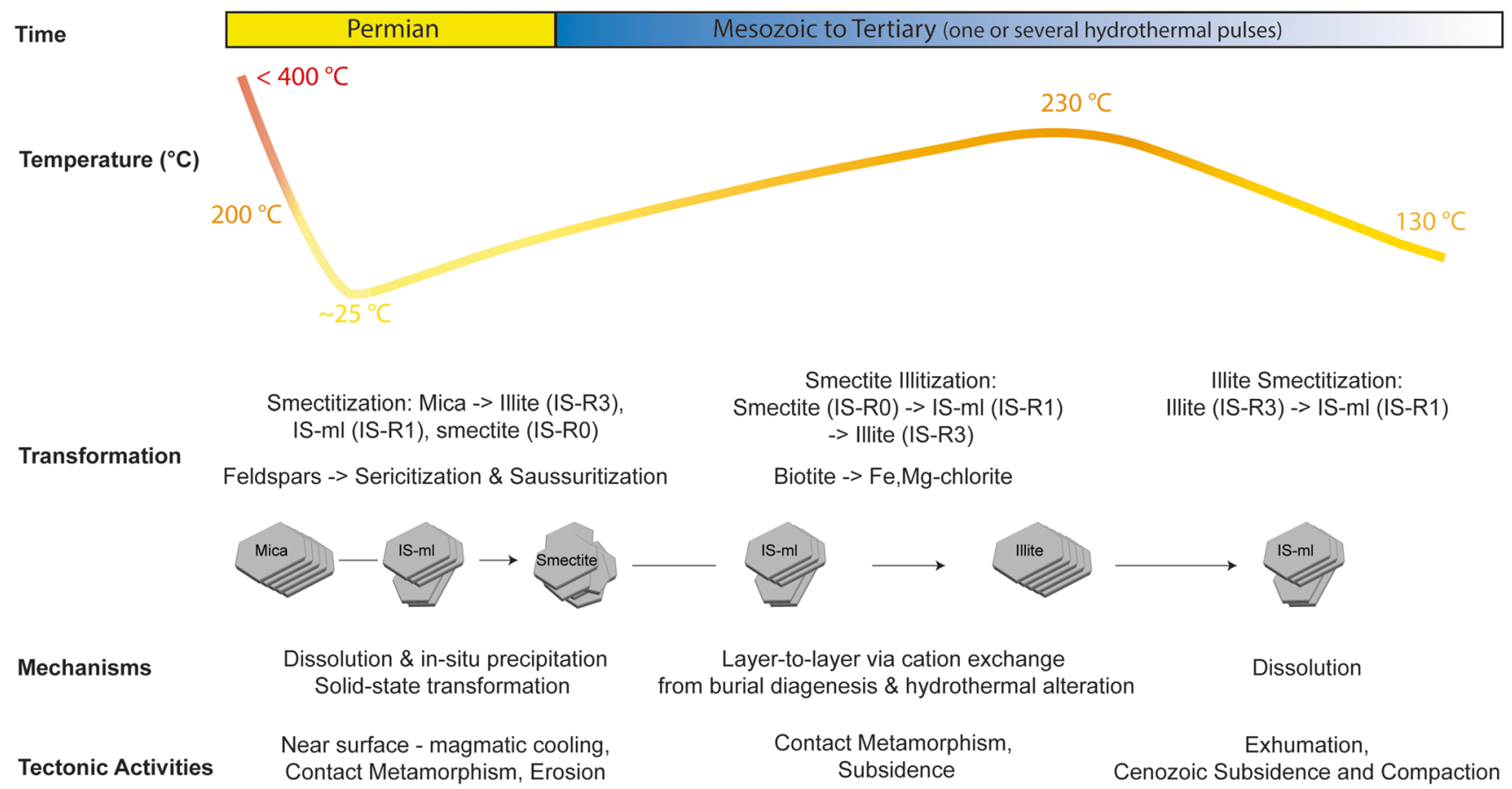

Fig. 7 Visualization of rhyolite transformation of clay minerals 
rhyolites contain mainly quartz, K-feldspar, and mica (biotite + muscovite). Therefore, it can be stated that primary feldspars were altered by sericitization and saussuritization, and the smectitization happened to primary mica resulting in illite (IS-R3), IS-ml (IS-R1), and smectite (IS-R0).

The sericitization and saussuritization of feldspars (both phenocrysts and glassy matrix) lead to the formation of chlorite, illite, and carbonates observed by both PM and XRD. The association of epidote and plagioclase (observed by PM) is also a proof for the sericitization process, which resulted in the formation of sericite and a more sodic plagioclase and releasing of $\mathrm{Ca}^{2+}$; then, this plagioclase combined with other components to form epidote by a reaction: Plagioclase $-1+\mathrm{K}^{+}+\mathrm{Na}^{+}+\mathrm{Mg}^{2+}+\mathrm{Fe}^{3+}+\mathrm{H}_{2} \mathrm{O} \rightarrow$ Sericite $+\mathrm{Pla}-$ gioclase $-2+\mathrm{Ca}^{2+} \rightarrow$ Epidote. The other components could be leased when the glassy matrix of rhyolites reacted with water, as described by Hay and Sheppard (2001). They mentioned that the process could also form void and fissure. The observed illite/muscovite with hydrothermal-flow structure could be the results of this mentioned process. According to Warr and Ferreiro Mählmann (2015), the sericitization to form IS-R1 represented a trend of alteration to high-grade diagenetic zone.

However, no kaolinite component, which is a typical near-surface alteration product of feldspars, was found for the studied material. Yuan et al. (2019) explained that high potassium level actively promotes feldspars (and even kaolinite formed early) forming illite/muscovite. The authors also reviewed that when the system reaches a steady state among the fluid-K-feldspar-illite-quartz, then K-feldspar dissolves to form illite and quartz directly following the equation $3 \mathrm{KAlSi}_{3} \mathrm{O}_{8}$ (K-feldspar) $+2 \mathrm{H}^{+} \rightarrow \mathrm{KAl}_{3} \mathrm{Si}_{3} \mathrm{O}_{10}(\mathrm{OH})_{2}$ (illite/muscovite) $+6 \mathrm{SiO}_{2}+2 \mathrm{~K}^{+}$. The slightly acidic geothermal fluids in Central and Northern URG (Dezayes et al. 2015) can favor this reaction.

With the mentioned proofs, the transforming feldspars into illite and other related minerals followed the dissolution and in situ precipitation mechanism. The depletion of $\mathrm{SiO}_{2}$ composition in the bulk samples (XRF result, Table 2) compared to the normal fresh rhyolites can be explained by the mobilization of dissolved Si from alteration of feldspars and mica, which were described by Dubois et al. (2000). With the dominant $\mathrm{K}$-feldspar in the normal fresh rhyolite, the dissolution can release $\mathrm{Al}^{3+}, \mathrm{Si}^{4+}, \mathrm{K}^{+}$, and a small amount of $\mathrm{Na}^{+}$and $\mathrm{Ca}^{2+}$. This process at a higher temperature develops the faster hydrolysis reaction (Hay and Sheppard 2001). This solution leads to the growth of neo-formed minerals discussed and also supports the transformation of other phases, such as mica into smectite and IS-ml. The dioctahedral phyllosilicates, formed by dissolution of volcanic rocks and precipitation directly from fluids, were extensively described by Bauluz et al. (2002), Inoue et al. (2005), and Murakami et al. (2005). The high brine solution in URG fluids (Sanjuan et al.
2014, 2016; Dezayes et al. 2015) could act as an additional reaction promoter for this transformation.

Regarding chemical characteristics, all of the IS-ml and end-member phases were identified with Al-rich, but also available $\mathrm{Mg}$ and $\mathrm{Fe}$ in the octahedral layer (Fig. 4, Table 4); and the bulk materials were relatively enriched of $\mathrm{Al}_{2} \mathrm{O}_{3}$ (Table 2). The solution with released $\mathrm{Al}^{3+}$ could facilitate these characteristics. The high brine fluids also support $\mathrm{Na}^{+}$ for the formation of Na-smectite and IS-ml. The Na-smectite formation from hydrolysis reaction of altered volcanic rocks was demonstrated by some studies used the thermodynamic model (Tomita et al. 1993; Cuadros et al. 1999; Hodder et al. 1993). The xenomorphic flakes of smectite observed by TEM (Fig. 6) fit with a footprint of the precipitation mechanism. This phase was also detected by XRD for clay fraction (Table 5, Figs. 5, 6), but with the tiny amount. The illitization that happened with most of the former smectite amount can be the answer. By all of the used methods for both bulk samples and clay fractions, the IS-ml phase showed domination in the studied materials. It is proof of the change from the main mica phase of the primary rhyolite. The presences of pseudo-hexagonal illite $2 M_{1}$ (IS-R3) and elongated IS-ml $1 M$ (IS-R1) are typical for precipitated particles (Rosenberg 2002; Inoue et al. 1987, 2005). In particular, the aggregation of elongated particles could be the result of a dissolution of primary platy mica and evolvement of the larger particles following the Ostwald ripening theory (Lifshitz and Slyozov 1961; Baronnet 1984). The sharp-edge laths are interpreted to primary mica. Left, the other morphologies of IS-ml identified with TEM for the studied samples (Fig. 6) are probably products of the solid-state alteration, which was reported by Yoder and Eugster (1955), Velde (1965), and Christidis (1995).

In conclusion, alteration of the primary rhyolites during magma cooling and possible contact metamorphisms with decreasing and low temperature happened following 2 mechanisms: dissolution-precipitation and solid-state transformation. The first one could lead to the alteration of glassy matrix and phenocrysts with the dominant association of feldspars, mica, and quartz to the neo-formed phases, including xenomorphic smectite, pseudo-hexagonal illite, and elongated IS-ml (sericite) and epidote. The other morphologies of IS-ml evolved with the second mechanism. Regarding the IS-ml and end-member phases, only a small amount of mica has not suffered from the alteration processes.

\section{Smectite illitization by hydrothermal alteration and burial diagenesis}

As discussed above, the alteration process happened under the contact metamorphisms and subsidence with the increasing temperature range of $140-230^{\circ} \mathrm{C}$. The environment conditions support smectite illitization to form IS-ml, including 
IS-R1 and IS-R3 orders, correspondingly $1 M$ and $2 M_{1}$ polytypes. The previous section mentioned the very small amount of discrete smectite remained due to illitization. The pseudo-hexagonal illite IS-R3 and elongated IS-R1 phases were referred to as products of the dissolution-precipitation process with decreasing temperature. The plates of IS-R1 and IS-R3 were neo-formation of the smectite illitization.

The most common illite and IS-ml are formed directly from smectite (Hower et al. 1976; Frey and Robinson 1999; Wang et al. 2017). The transformation sequence of smectite to illite via interstratifications occurs with a variation in the proportion of smectitic $(\% S)$ and illitic $(\% I)$ layers regardless of the geological environment. With the observed IS-ml series and $\% S$ values for the studied material, the smectite illitization continuously changed the ordering of layer stacking from randomly ordered smectite with $\% S=90-100$ to short-range ordered IS-ml $(\% S=15-40 \%)$ and long-range ordered IS-ml $(\% S<10 \%)$ and end-member illite/muscovite. Similar changes were described by many studies (Inoue and Utada 1983; Árkai 1991; Hillier 1995; Merriman and Peacor 1999).

Regarding chemical structure, smectite illitization process where the smectitic layer converted into the illitic layer parallel with the gradual increase of $\mathrm{Al}^{3+}$ for $\mathrm{Si}^{4+}$ tetrahedral substitution, and preferential absorption of $\mathrm{K}^{+}$. The fixed ion is preferred over $\mathrm{Na}^{+}, \mathrm{Ca}^{2+}$, and $\mathrm{Mg}^{2+}$ exchangeable ions in the interlayer sheet as described by Hower et al. (1976) and Hoffmann and Hower (1979). The source of $\mathrm{K}^{+}$was from $\mathrm{K}$-feldspar, and the source of $\mathrm{Al}^{3+}$ was from feldspar and mica.

The micaceous minerals evolved from an earlier CM population through the hydrothermal illitization were shown by the previous interpretations using $\mathrm{CM}$ geothermometer in several active geothermal sites, such as Wairakei-New Zealand (Steiner 1977), Kakkonda-Japan (Inoue et al. 2004), and Miravalles-Costa Rica (Rochelle et al. 1989). Smectite illitization was also found a dominant transformation during burial diagenesis by many studies, such as Pollard (1971), Bell (1986), Veblen (1992), Altaner and Ylagan (1997), and Bauluz et al. (2002). The transformation from IS-R0 to IS-R1 is comparable to CM reaction in the low-grade diagenesis (Środoń and Eberl 1984; Wang et al. 1996).

Results from hydrothermal alteration and burial diagenesis during Mesozoic eon in Northern URG include not only IS-ml series but also $\mathrm{Fe}, \mathrm{Mg}$-chlorite. $\mathrm{Fe}, \mathrm{Mg}$-chlorite was found as growth/stack with mica by PM (Fig. 2b, e) and detected as the minor phase by XRD in both bulk rocks and clay fractions (Table 2, Fig. 4). Furthermore, the amounts of chlorite increased with the depth (Table 2), indicating the higher burial diagenesis. The chlorite-muscovite is the transformation product from biotite described by Piqué and Wybrecht (1987) and Bozkaya et al. (2002). Spötl (1992) explained this transformation by the substitution of brucite-like layer for $\mathrm{K}^{+}$in the interlayer of biotite and the enrichment of $\mathrm{Mg}$ properly related to evaporitic fluids. Sullivan et al. (1994) and Wilkinson et al. (2001) mentioned that the biotite chloritization process could happen before the transformation of smectite to illite by fixation of interlayer $\mathrm{K}^{+}$under low burial diagenesis or hydrothermal temperature.

With the above discussion, the layer-to-layer via cation exchange is specified as a mechanism for smectite illitization and biotite chloritization. Reynolds and Hower (1970) stated this mechanism to explain the growth sequence of smectite illitization. By this mechanism, the smectitic layer is continuously converted into the illitic layer in which ions diffuse through the hydrous interlayer leading to substitutions in the different structural sheets, and thus, sheet distortion occurs. However, the small amount of discrete smectite with $\mathrm{Na}$ dominated in the interlayer has remained in the altered rhyolite. This can be explained that the smectite particles finally did not have enough time to alter completely to IS-ml and mica when the environmental conditions changed. Nasmectite was considered a "sleeper" with a low rate of alteration (Nguyen-Thanh et al. 2014). Therefore, this phase probably was comparatively stable in the evolution of the rock.

In short, smectite illitization with the mechanism of layerto-layer via cation exchange lead to the IS-ml series during the hydrothermal interaction and subsidence. The IS-ml series include the main phases of IS-R $11 M$ and IS-R $32 M_{1}$ as well as the minor phase of end-member illite/muscovite. The mechanism also results in the neo-formation of chlorite.

\section{Illite smectitization with decreasing temperature}

During the end of the Mesozoic eon and the Cenozoic eon, the temperature decreased because of the rising or light subsidence. However, the temperature is stable at around $\sim 130{ }^{\circ} \mathrm{C}$ with the present-day hydrothermal resources. This temperature is favorable for short-range ordered (IS-R1 $1 M$ ), which is dominant phase in the material samples (Table 3). Perhaps, the illite smectitization happened with an amount of IS-R3 $\left(2 M_{1}\right)$ formed by the illitization discussed in the previous section.

The layer-to-layer mechanism or the solid-state alteration, which was mentioned in the Sect. 5.2 (smectitization during magma cooling) for plates of IS-ml, is also consistent with the $2 M_{1}$-to- $1 M$ transformation during this time. This mechanism need an increasing of the water activity, which conforms to the tectonic activities.

The coexistence of all IS-R0, IS-R1, and IS-R3 orders in the studied material demonstrates that the IS-ml phases are metastable under the $T-P-t-X$ conditions prevailing in Northern URG. Although the $P-t-X$ conditions have not been fully clarified, the unclear difference between different samples at different depths (3500-3735 m) verifies the above statement. However, the much lower layer may present 
a significantly higher IS-R3 or illite/muscovite proportion, because the illite smectitization has not happened.

During the complex geological evolution, the IS-ml and end-member phases include three different generations as discussed above. This conclusion agrees with Schleicher et al. (2006), who used the K-Ar method and found at least three episodes of illite crystallization related to the hydrothermal environment in Permian, Jurassic, Cretaceous, or even younger time of the Soultz-sous-Forêts granite.

Studies about clays have been recent of great interest to geothermal prospection in URG because of physical-chemical changes controlling the permeability of the host rocks caused by hydrothermal alteration processes (Schleicher et al. 2006; Aretz et al. 2015; Vidal and Genter 2018; Vidal et al. 2018). According to Charléty et al. (2007), the development of secondary minerals and the transformation of silicates into CMs were strongly affected the hydraulic and mechanical properties of the rock. In particular, the permeability/porosity of the rock was drastically reduced and strongly depended on the structure of CMs. However, Bartier et al. (2008) found a reduction of Soult granite permeability by illite formation. With the CMs found, the upper $3700 \mathrm{~m}$ of altered Permian rocks in the deep geothermal borehole of Northern URG show a considerable amount of swelling population. The swelling CMs can affect the rock porosity and fracture sealing. It may become interesting for hydrothermal prospection in the Rotliegend below the rhyolite rocks if hot fluids can be trapped and/or higher porosity rocks can be presented. To get a conclusive clay formation history and timing of mineralization, similar studies are needed for younger rocks or suitable sediments to discriminate clay populations in different stratigraphic levels.

\section{Conclusions}

The CM formation in the Permian Donnersberg Formation of a geothermal borehole in Northern URG has been identified with the integration of XRF, PM, XRD, FT-IR, and TEM methods for both bulk rocks and clay fractions (Table 1). The primary rhyolite rocks have been drastically altered with a consecutive hydrothermal system. The altered material was semi-quantified with the depletion of $\mathrm{SiO}_{2}$ (53.3-57.0 wt\%, Table 2) and $\mathrm{K}_{2} \mathrm{O}(6.43-7.22 \mathrm{wt} \%)$, as well as the enrichment of $\mathrm{Al}_{2} \mathrm{O}_{3}(19.5-22.6 \mathrm{wt} \%)$ in comparison with the normal fresh rhyolites. Only a small amount of feldspar and mica (as sharp-edge laths, Figs. 2, 6) remained as primary phases. The mineral composition changed involves IS-ml and end-members, feldspars (mostly sericitized and saussuritized), quartz, chlorite, epidote, calcite, dolomite, and hematite (Tables 1, 3, Figs. 2, 3, 6). The dominant IS-ml and end-members make up 38-85 wt\% (Table 3) and include IS-R $11 M$ with $\% S=15-40$, IS-R3 $2 M_{1}$ with
$\% S<10$, end-member illite/muscovite IS-R3 $2 M_{1}$, and small amount of end-member smectite IS-R0 $1 M_{d}$. This series is characterized by a favorable $\mathrm{Al}^{3+}$ in the structure (Fig. 4, Table 4). Focusing on the alteration of these CMs, the study points out six stages for the evolution of the studied material, correspondingly three transformation processes (Fig. 7).

The first transformation happened during magma cooling and possible contact metamorphisms with decreasing and low temperature: from $<400$ to $\sim 200{ }^{\circ} \mathrm{C}$ then to $\sim 25^{\circ} \mathrm{C}$. Within this process, both the dissolution-precipitation and solid-state transformation mechanisms were identified based on the texture of the rock (such as illite/muscovite with hydrothermal-flow structure) as well as the morphology, structure/polytype, and chemistry of minerals (Tables 4 , 5, Figs. 4, 5, 6). The dissolution-precipitation mechanism could lead to the neo-formed xenomorphic discrete $\mathrm{Na}$ smectite, pseudo-hexagonal illite and elongated IS-ml (sericite), and epidote. The solid-state transformation reasonably formed the plates of IS-ml ( $1 M$ and $\left.2 M_{1}\right)$.

The second transformation was controlled by hydrothermal alteration and burial diagenesis with significant increasing temperature, from 140 to $170-\sim 230^{\circ} \mathrm{C}$. During this period, smectite illitization with the prevailed mechanism of layer-to-layer via cation exchange, which leads continuous changes from randomly ordered smectite: from $\% S=90-100$ to short-range ordered IS-ml $(\% S=15-40 \%)$ and long-range ordered IS-ml $(\% S<10 \%)$ and end-member illite/muscovite. Primary biotite was altered to $\mathrm{Fe}, \mathrm{Mg}$-chlorite with the same mechanism. This period may not favor and long enough to change all of the Na-smectite particles.

The third transformation followed exhumation and Cenozoic subsidence with decreasing temperature to $\sim 130{ }^{\circ} \mathrm{C}$ of present-day hydrothermal activities. The layer-to-layer mechanism is also consistent to convert long-range ordered IS-ml to short-range ordered IS-ml. The coexistence of all orders/polytypes in the studied material suggested that the IS-ml phases are metastable under the present-day conditions in Northern URG. The IS-ml series has drastically reduced the permeability/porosity of the rock.

Supplementary Information The online version contains supplementary material available at https://doi.org/10.1007/s00531-021-02022-y.

Acknowledgements This work was supported by the Hessian Agency for Nature Conservation, Environment and Geology and the Technical Petrology, Technical University of Darmstadt. We thank the local energy supplier ÜWG Stromnetze GmbH and Co. KG for allowance to publish analytical data and the study. ÜWG and GeoThermal Engineering $\mathrm{GmbH}$ are appreciated for the materials as well as the geological and structural information. We thank Pham Thi Nga (VNU University of Science) who performed the TEM-measurement. These results are the first harvest of a successful cooperation between the energy supplier, the private company, the governmental institution, and the universities. And last, but certainly not least, we are grateful to Prof. Reinhard Gaupp (Friedrich-Schiller-Universität Jena) and the anonymous reviewers for their careful reading of our manuscript and their 
many insightful comments and suggestions, which definitely help to improve the quality of this manuscript.

Funding Open Access funding enabled and organized by Projekt DEAL.

Open Access This article is licensed under a Creative Commons Attribution 4.0 International License, which permits use, sharing, adaptation, distribution and reproduction in any medium or format, as long as you give appropriate credit to the original author(s) and the source, provide a link to the Creative Commons licence, and indicate if changes were made. The images or other third party material in this article are included in the article's Creative Commons licence, unless indicated otherwise in a credit line to the material. If material is not included in the article's Creative Commons licence and your intended use is not permitted by statutory regulation or exceeds the permitted use, you will need to obtain permission directly from the copyright holder. To view a copy of this licence, visit http://creativecommons.org/licenses/by/4.0/.

\section{References}

Altaner SPA, Ylagan RF (1997) Comparison of structural models of mixed layer illite/smectite and reaction mechanisms of smectite illitization. Clay Clay Miner 45:517-533

Aquilina L, Pauwels H, Genter A, Fouillac C (1997) Water-rock interaction processes in the Triassic sandstone and the granitic basement of the Rhine Graben: geochemical investigation of a geothermal reservoir. Geochim Cosmochim Acta 61:4281-4295

Aretz A, Bär K, Götz AE, Sass I (2015) Outcrop analogue study of Permocarboniferous geothermal sandstone reservoir formations (northern Upper Rhine Graben, Germany): impact of mineral content, depositional environment and diagenesis on petrophysical properties. Int J Earth Sci (Geo Rundsch) 105:1431-1452

Arikas K (1986) Geochemie und Petrologie der permischen Rhyolithe in Südwestdeutschland (Saar-Nahe-Gebiet, Odenwald, Schwarzwald) und in den Vogesen. Pollichia-Buch 8:1-321

Árkai P (1991) Chlorite crystallinity: an empirical approach and correlation with illite crystallinity, coal rank and mineral facies as exemplified by Palaeozoic and Mesozoic rocks of northeast Hungary. J Metamorph Geol 9:723-734

Árkai P, Abad I, Nieto F, Németh T, Horváth PK, Judik K, JiménezMillán J (2012) Retrograde alterations of phyllosilicates in lowgrade metapelite: a case study from the Szendro-Paleozoic, NEHungary. Swiss J Geosci 105:263-282

Bailey W (1988) X-ray diffraction identification of the polytypes of mica, serpentine, and chlorite. Clay Clay Miner 36:193-213

Baronnet A (1984) Growth kinetics of the silicates, a review of the basic concepts. Fortschr Miner 62:187-232

Bartier D, Ledésert B, Clauer N, Meunier A, Liewig N, Morvan G, Addad A (2008) Hydrothermal alteration of the Soultz-sousForêts granite (hot fractured rock geothermal exchanger) into a tosudite and illite assemblage. Eur J Mineral 20:131-142. https:// doi.org/10.1127/0935-1221/2008/0020-1787

Bauluz B, Peacor DR, Ylagan RF (2002) Transmission electron microscopy study of smectite illitization during hydrothermal alteration of a rhyolitic hyaloclastite from Ponza, Italy. Clay Clay Miner 50:157-173

Bell TE (1986) Microstructure in mixed-layer illite/smectite and its relationship to the reaction of smectite to illite. Clay Clay Miner 34:146-154

Bergmann J, Friedel P, Kleeberg R (1998) BGMN: a new fundamental parameters based Rietveld program for laboratory X-ray sources, it's use in quantitative analysis and structure investigations. CPD Newslett Commiss Powder Diffract Int Union Crystallogr 20:5-8

Bethke GM, Vergo N, Stephen A, Altaner P (1986) Pathways of smectite illitization. Clay Clay Miner 4:135-136

Bird DK, Helgeson HC (1981) Chemical interaction of aqueous solutions with epidote-feldspar mineral assemblages in geologic systems. II. Equilibrium constraints in metamorphic/geothermal processes. Am J Sci 281:576-614

Bishop J, Madejová J, Komadel P, Fröschl H (2002) The influence of structural $\mathrm{Fe}, \mathrm{Al}$ and $\mathrm{Mg}$ on the infrared $\mathrm{OH}$ bands in spectra of dioctahedral smectites. Clay Miner 37(4):607-616

Boiron M, Cathelineau M, Richard A (2010) Fluid flows and metal deposition near basement/cover unconformity: lessons and analogies from $\mathrm{Pb}-\mathrm{Zn}-\mathrm{F}-\mathrm{Ba}$ systems for the understanding of Proterozoic U deposits. Geofluids 10:270-292

Bozkaya Ö, Yalçin H, Göncüoğlu MC (2002) Mineralogical and organic responses to stratigraphic irregularities: an example from the Lower Paleozoic very low-grade metamorphic units of the Eastern Taurus Autochthon, Turkey. Schweiz Mineral Petrol Mitt 82:355-373

Bozkaya Ö, Bozkaya UIT, Banks DA (2016) Illite occurrences related to volcanic-hosted hydrothermal mineralization in the Biga Peninsula, NW Turkey: implications for the age and origin of fluids. Ore Geol Rev 76:35-51

Brauckmann C (1983) Ein Insektenrest (Odonata, Meganisoptera) aus dem Ober-Karbon des Piesberges bei Osnabrück. Osnabrücker Nat 10:7-14

Brown G (1961) The X-ray identification and crystal structure of clay minerals. Mineralogical Society, London

Burisch M, Gerdes A, Walter BD, Neumann U, Fettelm M, Markl G (2017) Methane and the origin of five-element veins: mineralogy, age, fluid inclusion chemistry and ore forming processes in the Odenwald, SW Germany. Ore Geol Rev 81:42-61

Charléty J, Cuenot N, Dorbath L, Haessler H, Frogneux M (2007) Large earthquakes during hydraulic stimulations at the geothermal site of Soultz-sous-Forêts. Int J Rock Mech Min Sci 44(8):1091-1105

Christis GE (1995) Mechanism of illitization of bentonites in the geothermal field of Milos island Greece: evidence based on mineralogy, chemistry, particles thickness and morphology. Clay Clay Miner 43:569-585

Clauer N (2006) Towards an isotopic modeling of the illitization process based on data of illite-type fundamental particles from mixed-layer illite-smectite. Clay Clay Miner 54:116-127

Cuadros J, Caballero E, Huertas FJ, Jimenez C, Cisneros JD, Huertas F, Linares J (1999) Experimental alteration of volcanic tuff: smectite formation and effect on ${ }^{18} \mathrm{O}$ isotope composition. Clay Clay Miner 47:769-776

Dalla Torre M, Frey M (1997) The evolution from disordered Ad to ordered 2M1 white K-mica polytype in low-temperature metamorphosed rocks. Schweiz Mineral Petrogr Mitt 77(1):149-159

de Dunoyer Segonzac G (1970) The transformation of clay minerals during diagenesis and low-grade metamorphism: a review. Sedimentology 15:281-346

Dezayes C, Lerouge C (2019) Reconstructing paleofluid circulation at the Hercynian basement/Mesozoic sedimentary cover interface in the Upper Rhine Graben. Geofluids 2019:1-30

Dezayes C, Lerouge C, Sanjuan B, Ramboz C, Brach M (2015) Toward a better understanding of the fluid circulation in the Rhine Graben for a better geothermal exploration of the deep basins. In: World Geothermal Congress 2015, Melbourne, Australia

Dezes P, Schmid SM, Ziegler PA (2004) Evolution of the European Cenozoic Rift System: interaction of the Alpine and Pyrenean orogens with their foreland lithosphere. Tectonophysics $389: 1-33$ 
Doebl F, Heling D, Homann W, Karwei J, Teichmüller M, Welter D (1974) Diagenesis of Tertiary clayey sediments and included dispersed organic matter in relationship to geothermics in the Upper Rhine Graben. In: Illies JH, Fuchs K (eds) Approaches to taphrogenesis. Schweizerbart'sche Verl.-Buchh, Stuttgart, pp 192-207

Dornstadter J, Kappelmeyer O, Welter M (1999) The geothermal potential in the Upper Rhine Graben valley. In: Proceedings of European geothermal conference Basel 2, Basel, Switzerland, vol 2, pp 77-85

Dubois M, Ougougdal MA, Meere P, Royer JJ, Boiron MC, Cathelineau M (1996) Temperature of Palaeo-to modern self sealing within a continental rift basin: the fluid inclusion data (Soultzsous-Forêts, Rhine graben, France). Eur J Mineral 8:1065-1080

Dubois M, Ledesert B, Potdevin JL, Vancon S (2000) Détermination des conditions de précipitation des carbonates dans une zone d'altération du granite de Soultz (soubassement du fossé Rhénan, France). l'enregistrement des inclusions fluides. Comptes Rendus de l'Académie des Sci Ser IIA Earth Planet Sci 331:303-309

Eisbacher GH, Lüschen E, Wickert D (1989) Crustal-scale thrusting and extension in the Hercynian Schwarzwald and Vosges, Central Europe. Tectonics 8:1-21

Elliot WG, Matisoff G (1996) Evaluation of kinetic models for the smectite to illite transformation. Clay Clay Miner 44:77-87

Eslinger EV, Savin SM (1973) Oxygen isotope geothermometry of the burial metamorphic rock of the Precambrian Belt Supergroup, Glacier National Park, Montana. Bull Geol Soc Am 84:2549-2560

Essene EJ, Peacor DR (1995) Clay mineral thermometry: a critical perspective. Clay Clay Miner 43:540-553

Farmer VC (1974) The infrared spectra of minerals (Monograph 4). Mineralogical Society, London

Farmer VC, Russell JD (1964) The infrared spectra of layer silicates. Spectrochim Acta 20:1149-1173

Farmer VC, Russell JD (1967) Infrared absorption spectrometry in clay studies. Clay Clay Miner 15:121-142

Ferreiro Mählmann R (1994) Zur Bestimmung von Diagenesehöhe und beginnender Metamorphose-Temperaturgeschichte und Tektogenese des Austroalpins und Süpenninikums in Vorarlberg und Mittelbünden. Frankfurter geowissenschaftliche Arbeiten, C(14), p 498

Ferreiro Mählmann R (2001) Correlation of very low grade data to calibrate a thermal maturity model in a nappe tectonic setting, a case study from the Alps. Tectonophysics 334:1-33

Ferreiro Mählmann R, Potel S, Le Bayon R, Šegvić B, Nieto F (2012) The pioneer work of Bernard Kübler and Martin Frey in very low-grade metamorphic terranes: paleo-geothermal potential of variation in Kübler-Index/organic matter reflectance correlations: a review. Swiss J Geosci 105:121-152

Frey M (1970) The step from diagenesis to metamorphism in pelitic rocks during Alpine orogenesis. Sedimentology 15:261-279

Frey M (1987) Low temperature metamorphism. Blackie, Glasgow, p 351

Frey M, Robinson D (1999) Low-grade metamorphism. Blackwell Sciences, Oxford

Gaupp R, Matter A, Platt J, Ramseyer K, Walzebuck J (1993) Diagenesis and fluid evolution of deeply buried Permian (Rotliegende) gas-reservoirs, northwest Germany. Am Assoc Pet Geol B 77(7):1111-1128

Goodman BA, Russell JD, Fraser AR, Woodhams FWD (1976) A Mössbauer and IR spectroscopic study of the structure of nontronite. Clay Clay Miner 24:53-59

Grimmer JC, Ritter JRR, Eisbacher GH, Fielitz W (2017) The Late Variscan control on the location and asymmetry of the Upper Rhine Graben. Int J Earth Sci 106:827-853

Haneke J (1987) Der Donnersberg-zur Genese und stratigraphischen/ tektonischen Stellung eines permokarbonen Rhyolith-Domes im Saar-Nahe-Gebiet (SW-Deutschland). Pollichia-Buch $10: 1-147$

Harvey CC, Browne PRL (1991) Mixed-layer clay geothermometry in the Wairakei geothermal field, New Zealand. Clay Clay Miner 39:614-621

Hay RL, Sheppard RA (2001) Occurrence of zeolites in sedimentary rocks: an overview. In: Bish DL, Ming DW (eds) Reviews in mineralogy and geochemistry, vol 45. Mineralogical Society of America, Washington, DC

Heling D (1974) Diagenetic alteration of smectite in argillaceous sediments of the Rhinegraben (SW Germany). Sedimentology $21: 463-472$

Heling D (1978) Diagenesis of Illite in Argillaceous sediments of the Rhinegraben. Clay Miner 13:211

Heling D, Teichmüller M (1974) Die Grenze Montmorillonit/mixed layer-Minerale und ihre Beziehung zur Inkohlung in der Grauen Schichtenfolge des Oligozäns im Oberrheingraben. Forschr Geol Rheinl Westfalen 24:113-128

Henk A (1992) Mächtigkeit und Alter der erodierten Sedimente im Saar-Nahe-Becken (SW-Deutschland). Geol Rundsch 81(2):323-331

Henk A (1993) Subsidenz und Tektonik des Saar-Nahe-Beckens (SWDeutschland). Geol Rundsch 82:3-19

Henning KH, Störr M (1986) Electron micrographs TEM, SEM of clays and clay minerals. Akademie-Verlag, Berlin

Hillier S (1995) Erosion, sedimentation and sedimentary origin of clays. In: Velde B (ed) Origin and mineralogy of clays. Springer, Berlin, pp 162-219

Hillier S, Matyas J, Matter A, Vasseur G (1995) Illite/smectite diagenesis and its variable correlation with vitrinite reflection in the Pannonian Basin. Clay Clay Miner 43:174-183

HLNUG (2010) Nutzung tiefer Geothermie in Hessen. Hessian Agency for Nature Conservation, Environment and Geology. https:// www.hlnug.de/fileadmin/dokumente/geologie/erdwaerme/nutzu ng_tiefer_geothermie_hessen.pdf. Accessed 10 June 2019

Hodder APW, Naish TR, Nelson CS (1993) A two stage model for the formation of smectite from detrital volcanic glass under shallow marine conditions. Mar Geol 109:279-285

Hoffmann J, Hower J (1979) Clay mineral assemblages as low grade metamorphic geothermometers: application to the thrust faulted disturbed belt of Montana. In: Scholle PA, Schluger PR (eds) Aspects of diagenesis, vol 26. SEPM Society for Sedimentary Geology, London, pp 55-79

Horn P, Lippolt HJ, Todt W (1972) Kalium-Argon-Altersbestimmungen an tertiären Vulkaniten des Oberrheingrabens. Teil I. Gesamtgesteinsalter. Eclogae Geol Helv 65:131-156

Horsfield B, Rullkötter J (1994) Diagenesis, catagenesis, and metagenesis of organic matter. In: Magoon LB, Dow DG (eds) The petroleum system: from source to trap, vol 60. American Association of Petroleum Geologist Memoir, Washington, DC, pp 189-199

Horton DG (1985) Mixed-layer illite/smectite as a paleotemperature indicator in the Amethyst vein system, Creede district, Colorado, USA. Contrib Mineral Petrol 91:171-179

Hower J (1981) Shale diagenesi. In: Longstaffe FJ (ed) Short course in clays and resource geologist, vol 7. Mineralogical Association of Canada, Canada, pp 60-80

Hower J, Eslinger EV, Hower ME, Perry EA (1976) Mechanism of burial metamorphism of argillaceous sediment: 1. Mineralogical and chemical evidence. Geol Soc Am Bull 87:725-737

Huang WL, Longo JM, Pevear DR (1993) An experimentally derived kinetic model for smectite-to-illite conversion and its use as a geothermometer. Clay Clay Miner 41:162-177

Illies H (1962) Prinzipien der Entwicklung des Rheingrabens, dargestellt am Grabenabschnitt von Karlsruhe. Mitt Geol Staatsinst Hamb 31:58-122 
Illies JH (1975) Recent and palaeo-intraplate tectonics in stable Europe and the Rhinegraben rift system. Tectonophysics 29:251-264

Illies JH, Fuchs K (1974) Approaches to taphrogenesis. Schweitzerbarth, Stuttgart

Inoue A (1986) Morphological change in a continuous smectite-toillite conversion series by scanning and transmission electron microscope. J Coll Arts Sci Chiba Univ B 19:23-33

Inoue A, Utada M (1983) Further investigations of a conversion series of dioctahedral mica/smectites in the Shinzan hydrothermal alteration area, Northest Japan. Clay Clay Miner 31:401-412

Inoue A, Kohyama N, Kitagawa R, Watanabe T (1987) Chemical and morphological evidence for the conversion of smectite to illite. Clay Clay Miner 35:111-120

Inoue A, Velde B, Meunier A, Touchard G (1988) Mechanism of illite formation during smectite-to-illite conversion in a hydrothermal system. Am Mineral 73:1325-1334

Inoue AV, Meunier A, Beaufort D (2004) Illite-smectite mixed-layer minerals in felsic volcaniclastic rocks from drill cores, Kakkonda, Japan. Clay Clay Miner 52:66-84

Inoue AL, Marques-Fernandes M, Sakharov BA, Murakami T, Meunier A, Beaufort D (2005) Illite-smectite mixed-layer minerals in the hydrothermal alteration of volcanic rocks: I. One-dimensional XRD structure analysis and characterization of component layers. Clay Clay Miner 53(5):423-439

Jagodzinski H (1949) Eindimensionale Fehlordnung in Kristallen und ihr Einfluss auf die Röntgeninterferenzen. I. Berechnung des Fehlordnungsgrades aus den Röntgenintensitäten. Acta Cryst 2:201-207

Jennings S, Thompson GR (1986) Diagenesis of Plio-Pleistocene sediments of the Colorado River delta, Southern California. J Sediment Petrol 56:89-98

Jiang WT, Peacor DR, Merriman RJ, Roberts B (1990) Transmission and analytical electron microscopy study of mixed-layer illite/ smectite formed as an apparent replacement product of diagenetic illite. Clay Clay Miner 38:782-793

Keller G (2003) Biotic effects of impacts and volcanism. Earth Planet Sci Lett 215:249-264

Keller JB, Lorenz V, Sachs P (1990) Volcanism and petrology of the Upper Rhinegraben (Urach-Hegau-Kaiserstuhl). IAVCEI Int Volc Congress Mainz 1990. Field Guide, p 60

Kisch HJ (1987) Correlation between indicators of very low grade metamorphism. In: Frey M (ed) Low temperature metamorphism. Blackie, Glasgow, pp 227-300

Korsch RJ, Schaefer A (1991) Geological interpretation of DEKORP deep seismic reflection profiles $1 \mathrm{C}$ and $9 \mathrm{~N}$ across the Variscan Saar-Nahe Basin, south-west Germany. Tectonophysics 191:127-146

Kreuter H (2016) Erste Ergebnisse der Tiefbohrung Trebur GT1. 11. Tiefengeothermie-Forum, Darmstadt 2016

Kübler B (1967) La cristallinité de l'illite et les zones tout à fait supérieures du métamorphisme. In: Schaer JP (ed) Colloque sur les étages tectoniques. À La Baconnière, Neuchâtel, pp 105-121

Lifshitz IM, Slyozov VV (1961) The kinetics of precipitation from supersaturated solid solutions. J Phys Chem Solids 19:35-50

Lippolt HJ, Hess JC, Raczek I, Venlaff V (1989) Isotopic dating for the stratigraphic position of the Saar-Nahe Rotliegende volcanism II. Rb-Sr investigations. N Jahrb Geol Paläontol Monatsh 1989:539-552

Lorenz V, Nicholls IA (1976) The Permocarboniferous basin and range province of Europe. An application of plate tectonics. In: Falke H (ed) The continental Permian in Central, West, and South Europe. D. Reidel Publishing, Dordrecht, pp 313-342

Madejová J, Komadel P (2001) Baseline studies of the clay minerals society source clays: infrared methods. Clay Clay Miner 49:410-432
McDowell SD, Elders WA (1980) Authigenic layer silicate minerals in borehole Elmore 1, Salton Sea geothermal field, California. Contrib Minerol Petrol 74:293-310

Meier L, Eisbacher GH (1991) Crustal kinematics and deep structure of the northern Rhine Graben, Germany. Tectonics 10(3):621-630

Merriman RJ, Frey M (1999) Patterns of very low-grade metamorphism in metapelitic rocks. In: Frey M, Robinson D (eds) Lowgrade metamorphism. Blackwell Science, Oxford, pp 61-107

Merriman RJ, Kemp SJ (1996) Clay minerals and sedimentary basin maturity. Mineral Soc Bull 111:7-8

Merriman RJ, Peacor DR (1999) Very low-grade metapelites: mineralogy, microfabrics and measuring reaction progress. In: Frey MR (ed) Low-grade metamorphism. Blackwell Science, Oxford, pp $10-60$

Moore DE, Reynolds RC (1997) X-ray diffraction and the identification and analysis of clay minerals. Oxford University, Oxford

Muffler LJ, White DL (1969) Active metamorphism of Upper Cenozoic sediments in the Salton Sea Geothermal Field and the Salton Trough, Southeastern California. Geol Soc Am Bull 80:157-182

Müller H (1996) Das Permokarbon im nördlichen Oberrheingraben: Paläogeographische und strukturelle Entwicklung des permokarbonen Saar-Nahe-Beckens im nördlichen Oberrheingraben. Hessisches Landesamt f Umwelt u Geologie

Mullis J, Rahn MK, Schwer P, de Capitani C, Stern WB, Frey M (2002) Correlation of fluid inclusion temperatures with illite "crystallinity" data and clay mineral chemistry in sedimentary rocks from the external part of the Central Alps. Schweiz Mineral Petrogr Mitt 82:325-340

Mullis J, Ferreiro Mählmann R, Wolf M (2017) Fluid inclusion microthermometry to calibrate vitrinite reflectance (between 50 and $270{ }^{\circ} \mathrm{C}$ ), illite Kübler-Index and the diagenesis/anchizone boundary in the external parts of the Central Alps. Appl Clay Sci 143:307-319

Murakami T, Inoue A, Lanson B, Meunier A, Beaufort D (2005) Illitesmectite mixed-layer minerals in hydrothermal alteration of volcanic rocks: II. One-dimensional HRTEM structure-images and formation mechanism. Clay Clay Miner 53:440-451

Nguyen-Thanh L, Herbert HJ, Kasbohm J, Hoang-Minh T, Ferreiro Mählmann R (2014) Effects of chemical structure on the stability of smectites in short-term alteration experiments. Clay Clay Miner 62:425-446

Nieto F, Do Campo M (2020) Editorial for minerals special issue "From diagenesis to low-grade metamorphism." Minerals 10(10):879

Piqué A, Wybrecht E (1987) Origine des chlorites de l'épizone. Héritage et cristallisation synschsteuse. Exemple des grauwackes cambriennes du Maroc occidental. Bull Minér 110:665-682

Plein E (1992) Die Erdgasspeicher Hähnlein/Stockstadt. Jber Mitt Oberrh Geol 74:73-83

Pollard CO (1971) Semidisplacive mechanism for diagenetic alteration of montmorillonite layers to illite layers. Geol Soc Am Spec Pap 134:79-93

Pollastro RM (1993) Considerations and applications of the illite/smectite geothermometer in hydrocarbon-bearing rocks of Miocene to Mississippian age. Clay Clay Miner 41:119-133

Prodehl C, Müller S, Haak V (1995) The European Cenozoic rift system. In: Olsen K (ed) Continental rifts: evolution, structure, tectonics. Developments in geotectonics, vol 25. Elsevier, Amsterdam, pp 133-212

Pytte AM, Reynolds RC (1989) The thermal transformation of smectite to illite. In: Naeser ND, McCulloh TH (eds) Thermal history of sedimentary basins. Springer, New York, pp 133-140

Ramseyer K, Boles JR (1986) Mixed-layer illite/smectite minerals in Tertiary sandstones and shales, San Joaquin Basin, California. Clay Clay Miner 34:115-124 
Regensburg SF, Norden B, Tichomirowa M (2016) Fluid-rock interactions in a geothermal Rotliegend/Permo-Carboniferous reservoir (North German Basin). Appl Geochem 69:12-27

Reischmann T (2011) Tertiärer Vulkanismus. In: Kommission DS (ed) Stratigraphie von Deutschland IX-Tertiär. Teil 1: Oberrheingraben und benachbarte Tertiärgebiete (Schriftenreihe der Deutschen Gesellschaft für Geowissenschaften) 75 . Schweizerbart'sche, pp 16-130

Reynolds RC, Hower J (1970) The nature of interlayering in mixed layer illite-montmorillonite. Clay Clay Miner 18:25-36

Rochelle CA, Milodowski AE, Savage D, Corella M (1989) Secondary mineral growth in fractures in the Miravalles geothermal system, Costa Rica. Geothermics 18:279-286

Rosenberg PE (2002) The nature, formation, and stability of end-member illite: a hypothesis. Am Mineral 87:103-107

Rothe JP, Sauer K (1967) The Rhinegraben Progress Report 1967. International Upper Mantle Project. Sci Rep No 13. Abh Geol Landesamt Baden-Württemberg 6:1-146

Sanjuan B, Millot R, Dezayes Ch, Brach M (2010) Main characteristics of the deep geothermal brine $(5 \mathrm{~km})$ at Soultz-sous-Forêts (France) determined using geochemical and tracer test data. Comp Rendus Geosci 342:546-559

Sanjuan B, Millot R, Asmundsson R, Brach M, Griroud N (2014) Use of two new $\mathrm{Na} / \mathrm{Li}$ geothermometric relationships for geothermal fluids in volcanic environments. Chem Geol 389:60-81

Sanjuan B, Millot R, Innocent C, Dezayes C, Scheiber J, Brach M (2016) Major geochemical characteristics of geothermal brines from the Upper Rhine Graben granitic basement with constraints on temperature and circulation. Chem Geol 428:27-47

Schleicher AM, Warr LN, Kober B, Laverret E, Clauer N (2006) Episodic mineralization of hydrothermal illite in the Soultz-sousForêts granite (Upper Rhine Graben, France). Contrib Mineral Petrol 52:349-364

Schmitt AK, Marks MA, Nesbor HD, Markl G (2007) The onset and origin of differentiated Rhine Graben volcanism based on $\mathrm{U}-\mathrm{Pb}$ ages and oxygen isotopic composition of zircon. Eur J Mineral 19:849-857

Schoonmaker J, MacKenzie FT, Speed RC (1986) Tectonic implications of illite/smectite diagenesis, Barbados accretionary prism. Clay Clay Miner 34:465-472

Schumacher ME (2002) Upper Rhine Graben: role of preexisting structures during rift evolution. Tectonics 21:1-17

Schwarz MC (2005) Evolution und Struktur des Oberrheingrabensquantitative Einblicken mit Hilfe dreidimensionaler thermomechanischer Modellrechnungen. Dissertation, Albert-LudwigsUniversität Freiburg i. Breisgau

Schwarz M, Henk A (2005) Evolution and structure of the Upper Rhine Graben: insights from three-dimensional thermomechanical modelling. Int J Earth Sci 94:732-750

Seki Y (1972) Lower-grade stability limit of epidote in light of natural occurrences. J Geol Soc Jpn 78:405-413

Seki Y, Yurdakoc K (2007) Identification and characterization of Ferich smectites in the Çamlıca region of western Turkey. Clay Miner 42:153-160

Smith MP, Savary V, Yardley BWD, Valley JW, Royer JJ, Dubois M (1998) The evolution of the deep flow regime at Soultz-sousForêts, Rhine Graben, eastern France: evidence from a composite quartz vein. J Geophys Res 103(B11):223-237

Spötl C (1992) Clay minerals in Upper Permian evaporites from the Northern Calcareous Alps (Alpines Haselgebirge Formation, Austria). Eur J Mineral 4:1407-1419

Środoń J, Eberl DD (1984) Illite. In: Bailey SW (ed) Micas reviews in mineralogy, vol 13. Mineralogical Society of America, Washington, DC, pp 495-544
Środoń J, Clauer N, Eberl DD (2002) Interpretation of K-Ar dates of illitic clays from sedimentary rocks aided by modelling. Am Mineral 87:1528-1535

Starkey HC, Blackmon PL, Hauff PL (1984) The routine mineralogical analysis of clay-bearing samples. U.S. Geological Survey Bulletin, Washington, DC, p 1563

Steiner A (1968) Clay minerals in hydrothermally altered rocks at Wairakei, New Zealand. Clay Clay Miner 16:193-213

Steiner A (1977) The Wairakei geothermal area, North Island, New Zealand: its subsurface geology and hydrothermal rock alteration. N Z Geol Surv Bull 90:136

Stober I, Bucher K (2015) Hydraulic and hydrochemical properties of deep sedimentary reservoirs of the Upper Rhine Graben, Europe. Geofluids 15:464-482

Stollhofen H (1998) Facies architecture variations and seismogenic structures in the Carboniferous-Permian Saar-Nahe Basin (SW Germany): evidence for extension-related transfer fault activity. Sediment Geol 119:47-83

Sudo T, Shimoda S, Yotsumoto H, Aita S (1981) Electron micrographs of clay minerals. Elsevier, Amsterdam

Sullivan MD, Haszeldine RS, Boyce AJ, Rogers G, Fallick AE (1994) Late anhydrite cements mark basin inversion: isotopic and formation water evidence, Rotliegend sandstone, North Sea. Mar Pet Geol 11:46-54

Teichmüller M, Teichmüller R, Lorenz V (1983) Inkohlung und Inkohlungsgradienten im Permokarbon der Saar-Nahe-Senke. Z Dtsch Geol Ges 134:153-210

Tomita K, Yamane H, Kawano M (1993) Synthesis of smectite from volcanic glass at low temperature. Clay Clay Miner 41:655-661

Ufer K, Roth G, Kleeberg R, Stanjek H, Dohrmann R, Bergmann J (2010) Description of X-ray powder pattern of turbostratically disordered layer structures with a Rietveld compatible approach. Z Kristallogr 219:519-527

van der Marel HW, Beutelspacher H (1976) Atlas of infrared spectroscopy of clay minerals and their admixtures. Elsevier, Amsterdam, p 396

Vantelon D, Pelletier M, Barres O, Thomas F, Michot LJ (2001) Fe, $\mathrm{Mg}$ and $\mathrm{Al}$ distribution in the octahedral sheet of montmorillonites. An infrared study in the $\mathrm{OH}-$ bending region. Clay Miner 36:369-379

Veblen DR (1992) Electron microscopy applied to nonstoichiometry, polysomatism, and replacement reactions in minerals. In: Buseck PR (ed) Minerals and reactions at the atomic scale: transmission electron microscopy. Reviews in mineralogy, vol 27. Mineralogical Society of America, Washington, DC, pp 181-230

Velde B (1965) Experimental determination of muscovite polymorph stabilities. Am Mineral 50:436-449

Velde B (1977) Clays and clay minerals in natural and synthetic systems. Elsevier Science, Amsterdam, p 217p

Velde B (1985) Possible chemical controls of illite/smectite composition during diagenesis. Mineral Mag 49:387-391

Velde B, Nicot E (1986) Pressure-temperature-composition of illitee/ smectite mixed-layer minerals: Niger delta mudstones and other examples. Clay Clay Miner 24:435-441

Vidal J, Genter A (2018) Overview of naturally permeabile fractured reservoirs in the central and southern Upper Rhine Graben: Insights from geothermal wells. Geothermics 74:57-73

Vidal J, Patrier P, Genter A, Beaufort D, Dezayes C, Glaas C, Lerouge C, Sanjuan B (2018) Clay minerals related to the circulation of geothermal fluids in boreholes at Rittershoffen (Alsace, France). J Volcanol Geotherm Res 349:192-204

von Seckendorf V, Arz C, Lorenz V (2004) Magmatism of the late Variscan intermontane Saar-Nahe Basin (Germany): a review. In: Wilson M, Neumann ER, Davies GR, Timmermann MJ, Heeremans M, Larsen BT (eds) Permo-carboniferous magmatism 
and fifting in Europe, vol 223. Geological Society, London, pp 335-359

Wang H, Frey M, Stem WB (1996) Diagensis and metamorphism of clay minerals in the Helvetic Alps of Eastern Switzerland. Clay Clay Miner 44:96-112

Wang G, Zhang N, Wang H (2017) In situ high temperature X-ray diffraction study of illite. Appl Clay Sci 146:254-263

Warr L, Ferreiro Mählmann R (2015) Recommendations for Kübler Index standardization. Clay Miner 50(3):283-286

Weaver CE (1953) Mineralogy and petrology of some Ordovician K-bentonites and related limestones. Bull Geol Soc Am 64:921-944

Weaver CE (1960) Possible use clay minerals in search for oil. AAPG Bull 44:1505-1518

Weaver CE, Beck KC (1971) Clay-water diagenesis during burial: how mud becomes gneiss. Geological Society of America, Washington, DC, $\mathrm{p} 96$

Wedepohl KH, Baumann A (1999) Central European Cenozoic plume volcanism with OIB characteristics and indications of a lower mantle source. Contrib Mineral Petrol 136:225-239

Wenke A, Kreuter H, Gall W, Gutekunst S, Rohrer L, Zühlkem R (2010) First steps in the development of a new geothermal field in the Northern part of the Upper Rhine Graben, Germany. In: Proceedings Word Geothermal Congress: Bali, Indonesia, pp $25-29$
Whitney G (1990) Role of water in the smectite-to-illite reaction. Clay Clay Miner 38:343-350

Wilkinson M, Milliken KL, Haszeldine RS (2001) Systematic destruction of K-feldsparin deeply buried rift and passive margin sandstones. J Geol Soc Lond 158:675-683

Wimmenauer W (1952) Petrographische Untersuchungen an einigen basischen Eruptivgesteinen des Oberrheingebietes. N Jb Miner Abh 83:375-432

Wimmenauer W (1970) Zur Petrologie der Magmatite des Oberrheingrabens. Fortschr Mineral 47:242-262

Wimmenauer W (1972) Die Lamprophyre des Schwarzwaldes. Fortschr Mineral 50:34-37

Wimmenauer W (1985) Petrologie der magmatischen und metamorphen Gesteine. Enke, Stuttgart

Xue X, Wang W, Fan H, Xu Z, Pedruzzi I, Li P (2019) Adsorption behavior of oxalic acid at water-feldspar interface: experiments and molecular simulation. Adsorption 25:1191-1204

Yoder HS, Eugster HP (1955) Synthetic and natural muscovites. Geochim Cosmochim Acta 8:225-242

Yuan G, Cao Y, Schulz H-M, Hao F, Gluyas J, Liu K, Yang T, Wang Y, Xi K, Li F (2019) A review of feldspar alteration and its geological significance in sedimentary basins: from shallow aquifers to deep hydrocarbon reservoirs. Earth Sci Rev 191:114-140

Ziegler PA, Dezes P (2005) Evolution of the lithosphere in the area of the Rhine Rift System. Int J Earth Sci 94:594-614 